\title{
A REVISION OF THE GENUS FRITILLARIA (LILIACEAE) IN CROATIA
}

\author{
${ }^{1}$ Radovan Kranjěev \& ${ }^{2}$ Damir ŠešoK \\ ${ }^{1}$ Trg Eugena Kumičića 17, HR-48 000 Koprivnica, Croatia (e-mail: radovan.biol@gmail.com) \\ ${ }^{2}$ Petra Zrinskog 29, HR-48 317 Legrad, Croatia (e-mail: damir.sesok@hrsume.hr)
}

Kranjčev, R. \& Šešok, D.: A revision of the genus Fritillaria (Liliaceae) in Croatia. Nat. Croat., Vol. 25, No. 2., 185-212, 2016, Zagreb.

Botanical research into taxa of the genus Fritillaria (Liliaceae), which until today have not been fully identified and in the taxonomy of which there were ambiguities and confusion, was conducted on the entire territory of Croatia from 2012 to 2014. We studied the existing taxa in Croatia, partly also their ecology and certain features, taxonomy and distribution in the continental, coastal and island parts of Croatia. The name Fritillaria messanensis Raf. subsp. gracilis (Ebel) Rix caused most of the confusion with other taxa; however it was discovered at eight localities in southern Croatia, in the region of Konavle and the Dubrovnik Riviera. Based on the analysis of populations at 90 localities, five taxa were recognized and described: Fritillaria messanensis subsp. neglecta (Parl.) Nyman (endemic to Croatia), Fritillaria messanensis Raf. subsp. gracilis (Ebel) Rix, Fritillaria meleagris L., Fritillaria montana Hoppe ex W.D.J.Koch and Fritillaria graeca Boiss. \& Spruner subsp. thessala (Boiss.) Rix, with one locality on the island of Pag. The herbarium revision included four Croatian herbaria.

Key words: taxa, Fritillaria, ecology, distribution, taxonomy, Croatia

Kranjčev, R. \& Šešok, D.: Revizija roda Fritillaria (Liliaceae) u Hrvatskoj. Nat. Croat., Vol. 25, No. 2., 185-212, 2016, Zagreb.

Rad donosi rezultate botaničkog istraživanja svojti roda kockavica, Fritillaria (Liliaceae), koje do danas nisu bile potpuno određene i u čijoj taksonomiji je bilo nedoumica i zbrke, a koje je provedeno na cjelokupnom području Hrvatske od 2012. do 2014. godine. Proučavali smo postojeće svojte u Hrvatskoj, djelomično njihovu ekologiju i neke osobine, taksonomiju i rasprostranjenost u kontinentalnim, obalnim i otočnim dijelovima Hrvatske. Ime Fritillaria messanensis Raf. subsp. gracilis (Ebel) Rix uzrokovalo je najviše zbrke u odnosu na ostale svojte; svojta je utvrđena na osam lokaliteta u južnoj Hrvatskoj, u Konavlima i dubrovačkoj rivijeri. Na temelju analize populacija na 90 lokaliteta, utvrđeno je i opisano pet svojti: Fritillaria messanensis subsp. neglecta (Parl.) Nyman (endemična za Hrvatsku), Fritillaria messanensis Raf. subsp. gracilis (Ebel) Rix, Fritillaria meleagris L., Fritillaria montana Hoppe ex W.D.J.Koch i Fritillaria graeca Boiss. \& Spruner subsp. thessala (Boiss.) Rix, s jednim lokalitetom na otoku Pagu. Revizija herbarija uključila je četiri hrvatska herbarija.

Ključne riječi: svojte, Fritillaria, ekologija, rasprostranjenost, taksonomija, Hrvatska

\section{INTRODUCTION}

To date in Croatia there has been no systematic and comprehensive research into the taxa of the genus Fritillaria (Liliaceae), and it is not fully known which taxa inhabit its territory. We established that the rather unclear criteria for distinguishing individual taxa, the numerous synonyms and inadequate identification keys caused major problems in our work. In addition, the existing data on Fritillaria in Croatia in the last hundred years or more have not been taxonomically evaluated, so in that sense this work represents a revision of the current situation. The large number of populations shows the 
complete absence of flowering in some years, ,, an explosion“ of flowering in some populations, a flowering time difference of up to 30 days from the usual time of flowering, sympatric populations with synchronous or anachronous flowering with great population variability, large horizontal and especially vertical distribution and a relatively short period of flowering - all phenomena that require many years of field work.

The result is a relatively small total number of known localities for the genus Fritillaria in Croatia, except for the data about localities of F. meleagris L. (IlijAnić et al., 1998), to which we added nine localities, some of which were previously unknown. This paper does not include F. imperialis L. which is known in Croatia only as a horticultural plant.

The revised herbarium material of the genus Fritillaria from the four Croatian herbaria is given as specimina visa after each taxon, respectively.

\section{Previous research}

The taxa Fritillaria montana Hoppe ex W. D. J. Koch, F. messanensis Raf. and F. neglecta Parl. (Visiani, 1852; Parlatore, 1852) in the genus Fritillaria were recorded in the mid19th century for the regions of Dalmatia and Istria. The first systematic exploration of the entire Croatian flora (Schlosser-Vukotinović, 1869) recorded four taxa in the genus: F. meleagris L., F. montana Hoppe, F. messanensis Raf. and F. involucrata All. (Syn. F. nervosa Willd., F. pyrenaica Clus.). The number of localities in which they are found is increasing, while older localities to date have not been confirmed, for various reasons (urbanization, mines, changes in habitat conditions, inaccessibility). Such are, for example, Sv. Marko, Voz, Prolog, Visočica, Mosor. Fritillaria montana Hoppe ex W. D. J. Koch and F. involucrata were recorded for the area surrounding Dubrovnik (VIsiani, 1852; Adamović 1887, 1911). Fritillaria messanensis Raf. (Syn. F. pyreanica C. Presl), F. tenella M.Bieb. (Syn. F. montana Hoppe ex W. D. J. Koch), and F. neglecta Parl. were recorded for the area of the Croatian northern coast (Rossi, 1930). The Prodromus of Balkan Peninsula flora (HAYEK, 1932-1933) cites three taxa for the area of Croatia: F. meleagris L., F. tenella M.Bieb., F. gracilis (Ebel) Asch. \& Graebn. and F. liburnica B. Lengyel (Lengyel, 1933-1934) for Istria (Učka). Research into the flora of Velebit (DEGEN, 1936) revealed three taxa in the genus: F. meleagris L., F. montana Hoppe ex W. D. J. Koch and F. gracilis (Ebel) Asch. \& Graebn. A number of new localities that are mainly repetitive and likely to expand slightly had been stated for the latter. Degen's paper combines F. gracilis (Ebel) Asch. and F. neglecta Parl. into one taxon. Two taxa have been recorded in the flora of Biokovo: Fritillaria tenella M.Bieb. and Fritillaria gracilis (Ebel) Asch. \& Graebn. (KušAN, 1969; RIx, 1980), five taxa that occur in the southern part of the Balkans, that is, in the former Yugoslavia, have been recorded in the flora of Europe. Domac (1994) lists three taxa in the genus Fritillaria. The book Endemic Plants (ŠILIć, 1984) contains an error, the described taxon F. messanensis subsp. gracilis being accompanied by the image of the taxon F. messanensis subsp. neglecta (Parl.) Nyman, and not F. messanensis subsp. gracilis. During years of research into the flora of Mt. Velebit (Forenbacher, 1999), and not taking into account a generally accepted European taxonomy (RIx, 1980), three taxa were recorded: F. meleagris L., F. tenella M.Bieb. (and not F. orientalis Adams) and the non-existent F. gracilis Asch. \& Graebn. The picture disclosed in the book 'Velebit and its flora' shows F. messanensis subsp. neglecta (Parl.) Nyman, not F. messanensis Raf. subsp. gracilis (Ebel) Rix. The best known and most widespread F. meleagris L. has been recorded in a hundred or more localities in Croatia (IlijANIć et al., 1998). Taxonomic uncertainties continue to be present in the listing of Croatian flora (NiкоLı́́, 2000) which specifies four taxa for Croatia, where 
together with F. messanensis Raf. subsp. gracilis (Ebel) Rix, F. messanensis Raf. subsp. messanensis is listed, although until the present day it has not been confirmed in Croatia, in spite of the former Yugoslavia being given as a part of its range. The taxonomy and the nomenclature used there is outdated (RIX, 1980), as today the valid name for F. orientalis Auct. Fl. Eur. is F. montana Hoppe ex W.D.J.Koch.

The list of Croatian flora was the basis for the Croatian Red Book of Plant Species (Nikolić et al., 2005), where F. meleagris L. and F. messanensis Raf. subsp. gracilis (Ebel) Rix are listed as endangered, with all previous and a number of new localities, but under the name of the latter taxon there is a photograph that does not match the taxon or the accompanying text. Some localities in Croatia are listed in the description of the karyologic picture of $F$. messanensis Raf., and three taxa in the rank of subspecies are defined within this species (Kamari et al., 2006). Fritilaria montana Hoppe ex W.D.J.Koch with 2n $=18$ chromosomes was found at the locality Aržano (Aquaro et al., 2007).

Further analytical approach finally defined F. messanensis subsp. neglecta (Parl.) Nyman as a fourth subspecies, seemingly endemic to Croatia and described for Istria (PERUzzi et al., 2009). BARtolucci et al. (2009) studied also biometry of F. montana and PERUZZI \& BARTOLUCCI (2009) its complex from the central Mediterranean. This marks the setting of the taxonomic framework for the taxa of the genus Fritillaria in Croatia. However, in the Manual for determining the terrestrial habitats in Croatia (Topić et al., 2009), as well as in the Regulations on strictly protected species (Ministry of ENVIRONMENT and Nature Protection, 2013), the same taxonomic confusion and inconsistency is continued, even more so in studies of the flora of Istria (RotTENSTEINER, 2012). Describing the new localities of F. montana on the mountains of Papuk and Krndija, TomašEvić et al. (2012) expanded the so far known distribution of this taxon in Croatia; however, the photograph shows F. meleagris L. In documentation of the finding of Chouardia lakusicii (Šilić) Speta in the Dubrovnik area in Croatia, F. graeca Boiss. \& Spruner and F. messanensis Raf. subsp. gracilis (Ebel) Rix (Ruščić et al., 2012) are mentioned.

\section{MATERIAL AND METHODS}

From 2012 to 2014, and previously from time to time since 2000, research into taxa of the genus Fritillaria was conducted in Croatia. The research fundamentally consisted of fieldwork. This was the first time for research to be extended to the whole of Croatia. We tried to determine the current status of distribution of populations and to find as many populations as possible of existing taxa and by biometric and other kinds of analysis to identify taxa in the genus Fritillaria in Croatia.

Detailed biometric measurements were taken, based on the features of plants in various types of populations and the following data were recorded: date, name, altitude, coordinates, characteristics of habitats, population size (density) and surface. The data were obtained by examination and measurement of several specimens, at least 10-20, wherever possible. Samples were selected randomly, avoiding extremes, and their average values were recorded: stalk: height; leaf: number, arrangement of upper, middle and lower, dimensions, shape; flower: number, total length, width in the middle, colour, shape, fascia presence/absence, quadrant fields presence/absence; tepals: dimensions, top, colour; nectarium: distance from the base of the tepal, shape, dimensions, edges, colour and other. To highlight the nectarium, the tepal from the inside is shown by photography. Photographs of some characteristic habitats and some populations at the time of flowering are also shown, as well as individual specimens or groups of plants, and one unique sample. Numerous localities were visited at the time when the plants 
were fruiting and samples of seeds and fruits were photographed. Some animal pollinators, or those which feed on plant parts or have their microhabitats in dried fruits were also recorded.

Some of the localities were visited 2-3 times due to phenological anomalies or lack of flowering in a full population (Poštak, Ljubovo, Vučevica, Hvar - Sv. Nikola et al.). An effort was made to investigate the folk names of certain taxa that have been recorded in literature and/or are in use today. The distribution of all identified taxa in Croatia is shown on maps of the localities. All of the research into taxa of the genus Fritillaria in Croatia in this paper was conducted on living material. An exsiccate was made for each taxon except for F. meleagris.

In addition, revision of herbarium sheets of Fritillaria species was performed in four Croatian herbaria (ZA and ZAHO (Faculty of Science, University of Zagreb), ZAGR (Faculty of Agriculture, University of Zagreb), CNHM (Croatian Natural History Museum, Zagreb)).

\section{RESULTS}

\section{Habitats}

The most common habitats in Croatia are xerophylous grasslands of different vegetation types on a limestone substrate, almost from the sea level to the highest parts of mountains. Some taxa grow in rare but dense Mediterranean deciduous forests and thickets, so in early spring flowering plants prevail in some places. Only F. meleagris inhabits hydrophilic and periodically flooded grasslands, meadows and pastures, mainly in the northern lowland parts of Croatia. This species also appears, but rarely, within some lowland deciduous forest communities in areas with sparse vegetation, as well as on hydrophilic mountain meadows of Bunovac on Mt Velebit at a height of $1204 \mathrm{~m}$ a.s.1. (Fig. 1).

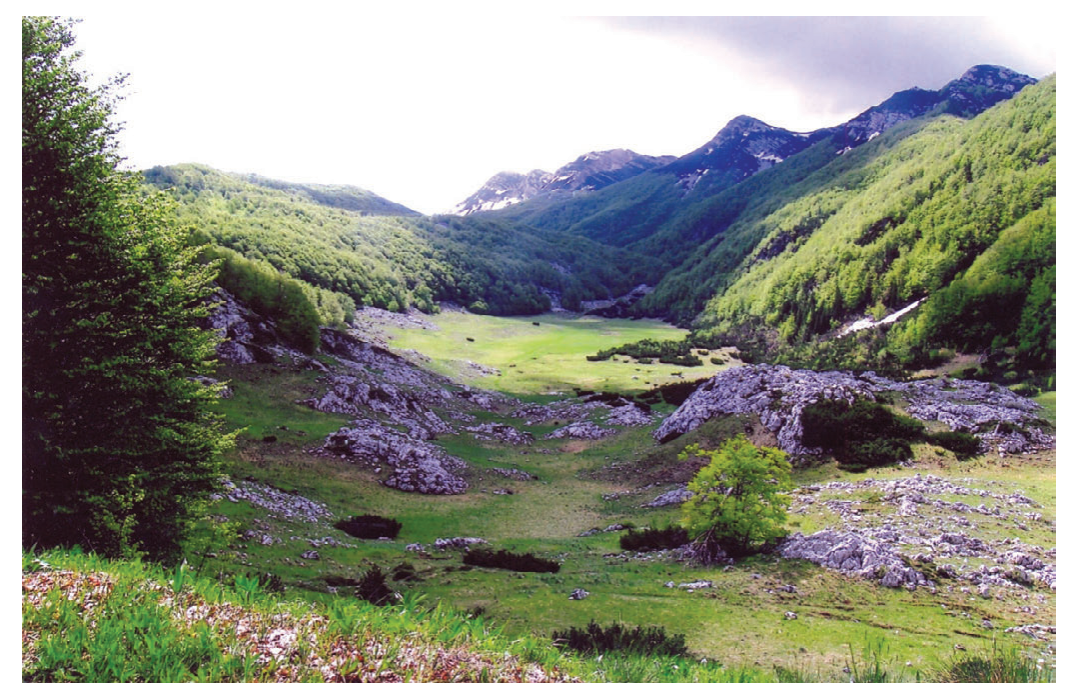

Fig. 1. Bunovac valley in southern Mt. Velebit. 


\section{Localities}

Only a fraction of the population is found at localities referred to in the literature and which we could geographically identify as such and determine their continuity. Senj and its surrounding area can be taken as an example of such a locality (no. 82). It was first mentioned in 1873 by Viktor Mihailović, a teacher at the Gymnasium of Senj (Mirailović, 1873), and also confirmed in the mid-20th century (Rossi, 1930), and a few years later (DEGEN, 1936) by the words "nur nach heute“. At the same locality we found $F$. montana in 2013, which indicates the continuity of its existence and finding during an interval of 140 years.

Some of the localities are given in the literature in general terms only, such as Lika, Dalmatia, Biokovo, Velebit, around Dubrovnik, and for us this had little practical value. At some localities from the literature we did not find any Fritillaria population.

The list of localities contains serial numbers and names (in bold) only of investigated populations with date, or dates, showing also the time or the time interval in which the flowering took place, or fruits were able to be found. Accurate coordinates of all localities are also marked.

1. Mt. Biokovo: Veliki Troglav, GPS N 43¹9’57,54" E 1703’24,05”, 1531 m, 19. V 2013. (F. messanensis subsp. neglecta)

2. Mt. Biokovo: Vošac, GPS N 43ำ $18^{\prime} 48,37^{\prime \prime}$ E $17^{\circ} 03^{\prime} 24,48^{\prime \prime}, 1332$ m, 19. V 2013. (F. montana)

3. Mt. Biokovo: Rasovo, GPS N 4317'49,92”, E 1704'27,82", 1265 m (F. montana)

4. Dalmatinska zagora: Blaca, surroundings of Vučevica, GPS N 433' $14,46^{\prime \prime}$ E 16²6'10,87", 419 m, 11. IV 2002, 3. IV 2003, 13. IV 2009, 24. IV 2009, 22. IV 2012, 29. VII 2012, 6. IV 2013, 20. IV 2013, 22. IV 2014 (F. montana, F. messanensis subsp. neglecta)

5. Dalmatinska zagora: Vučevica. GPS N 433' $16,66^{\prime \prime}$ E $16^{\circ} 26^{\prime} 12,36^{\prime \prime}, 412$ m, a unique specimen. (F. messanensis subsp. neglecta)

6. Dalmatinska zagora: Boraja, Vrsno, Belaci, GPS N 433' $51,25^{\prime \prime}$ E 1602' 46, $90^{\prime \prime}, 341$ m, 6. IV 2013. (F. montana)

7. Dalmatinska zagora: Šibenik, Bilice Donje, GPS N 43³7'51,25" E 1602'46, 90", 341 m, 6. IV 2013. (F. montana)

8. Dalmatinska zagora: Slivno, Radnići, GPS N 4340’49,16" E 1609'56,18", 276 m, 6. IV 2013. (F. montana)

9. Dalmatinska zagora: Svilaja, Maovice Gornje, Lemeš, GPS N 4352'43,61" E 16²0'41,03", 1033 m, 28. IV 2013, 23. IV 2014 (F. montana)

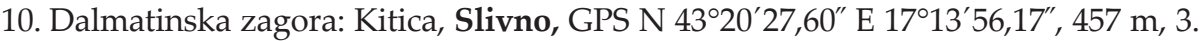
IV 2003, 3. V 2003, 7. IV 2013 (F. montana)

11. Dalmatinska zagora: Kitica, Poljica Kozička. GPS N 42 ${ }^{\circ} 18^{\prime} 18,40^{\prime \prime}$ E $17^{\circ} 14^{\prime} 47,60^{\prime \prime}$, 786 m, 27. IV 2012 (F. messanensis subsp. neglecta)

12. Dalmatinska zagora: Medov Dolac, Dobrinjče, GPS N $43^{\circ} 25^{\prime} 46,06^{\prime \prime}$ E $17^{\circ} 04^{\prime} 28,34^{\prime \prime}$, $581 \mathrm{~m}$, 7. IV 2013.(F. montana)

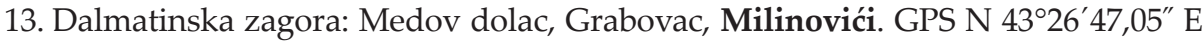
$17^{\circ} 00^{\prime} 59,42^{\prime \prime}, 422 \mathrm{~m}, 27$. IV 2012, 7.IV 2013 (F. montana)

14. Dalmatinska zagora: Unešić, Sučići, Mirlović Zagora, GPS N 4345’39,16" E $16^{\circ} 07^{\prime} 52,28^{\prime \prime}, 27$. IV 2012, 306 m (F. montana)

15. Dalmatinska zagora: Neorić, GPS N 4340’34,16" E 16³1'03,79", 464 m, 15. V 2002. In 2013 and 2014 entire population disappeared for unknown reason. Only one 
specimen of F. montana was recorded in 2012, which disappeared in 2014 (F. messanensis subsp. neglecta, F. montana).

16. Dalmatinska zagora: Svilaja, Orlove stine 1, GPS N 434ㄴ $33,75^{\prime \prime}$ E $16^{\circ} 31^{\prime} 35,19^{\prime \prime}$, 934 m, 14. IV 2009, 27. IV 2012, 21. IX 2012, 23. IV 2014 (F. montana)

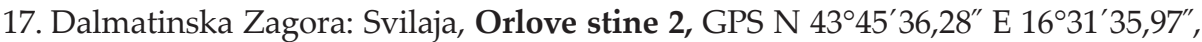
941 m, 22. IV 2008, 14. IV 2009., 27. IV 2012, 23. IV 2014 (F. messanensis subsp. neglecta)

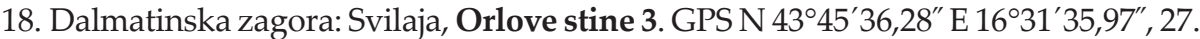
IV 2012, 23. IV 2014, 946 m (F. montana)

19. Kijevo: Kijevski bat, GPS N 435' 46,53" E 16²19’50,76". 1131 m, 25. IV 2007 (F. montana)

20. Dalmatinska zagora: Visočani, GPS N 42 $51^{\prime} 35,50^{\prime \prime}$ E $17^{\circ} 46^{\prime} 03,10^{\prime \prime} 182 \mathrm{~m}$, 23. IV 2012, 29. VII 2012, 19. IX 2012 (F. messanensis subsp. neglecta)

21. Dalmatinska zagora: Zelovo, GPS: N 4344'25,21" E 16³3'07,55", 833 m, 23. IV 2014 (F. montana)

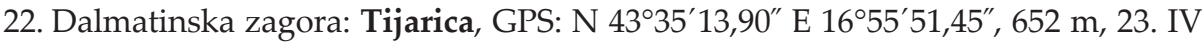
2014 (F. messanensis subsp. neglecta)

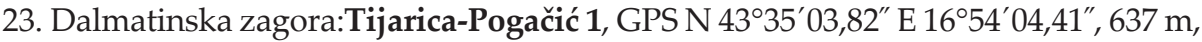
25. IV 2014 (F. montana, F. messanensis subsp. neglecta)

24. Dalmatinska zagora: Tijarica-Pogačić 2, GPS N 43³5'01,65" E 1654'01,20", 642 m, 25. IV 2014 (F. montana)

25. Međimurje: Donji Vidovec, Plavišće. GPS N 46²0’41,59" E 1645’53,54", 138 m;

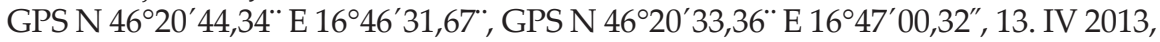
30. V 2013, 15. IV 2014 (F. meleagris)

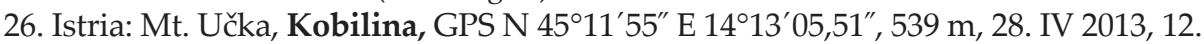
IV 2014, with Narcissus radiiflorus Salisb., Orchis pauciflora Tenore. (F. montana)

27. Istria: Mt. Učka, Orlić 1, GPS N 450'36,31" E 14¹1'20,59”, 553 m, 13. IV 2014 (F. messanensis subsp. neglecta)

28. Istria: Mt. Učka, Orlić 2, GPS N 4508’43,29” E 14¹1'11,79”, 530 m, 13. IV 2014 (F. messanensis subsp. neglecta)

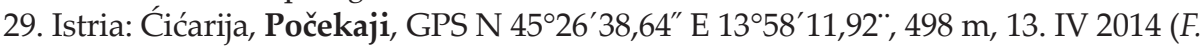
montana)

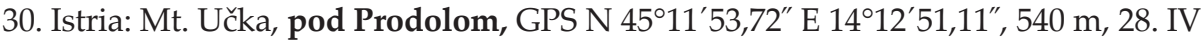
2013, 5. VIII 2013, 12. IV 2014 (F. messanensis subsp. neglecta)

31. Istria: Mt. Učka, Prodol, GPS N 4511'49,52" E 14¹2'15,12”, 562 m, 28. IV 2013, 15. VIII 2013, 12. IV 2014 (F. montana)

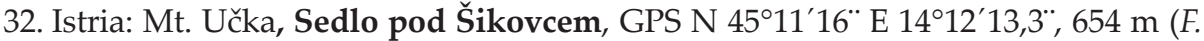
messanensis subsp. neglecta, locus classicus)

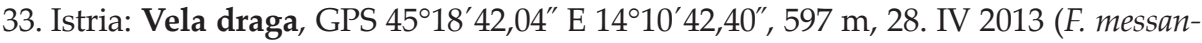
ensis subsp. neglecta)

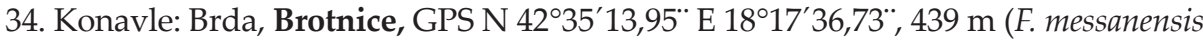
subsp. gracilis)

35. Konavle: Brda, Duba. GPS N 42³5’57,29” E $18^{\circ} 20^{\prime} 21,60^{\prime \prime}, 473$ m, 27. IV 2003, 27. III 2007, 25. IV 2014 (F. montana, F. messanensis subsp. gracilis)

36. Konavle: Brda, Duba selo 1, GPS N 42³5'57,75" E 18²0’44,11", 469 m, 25. IV 2014., with Peteria ramentacea (Sieb) Presl., Chouardia lakusicii (Šilić) Speta (F. messanensis subsp. neglecta, F. montana)

37. Konavle: Brda, Duba selo 2, GPS 42³5'57,33" E 18²0’43,78'. 25. IV 2014, $471 \mathrm{~m}$ (F. montana) 
38. Konavle: Brda, Stravča. GPS N 42 $35^{\prime} 56,44^{*}$ E 18¹9’14,31“" 485 m, 27. III 2008, 25. IV 2014 (F. messanensis subsp. gracilis)

39. Konavle: Brda, Stravča - Duba. GPS N 42 $35^{\prime} 55,90^{\prime \prime}$ E $18^{\circ} 19^{\prime} 08,39^{\prime \prime} .488$ m (F. messanensis subsp. neglecta)

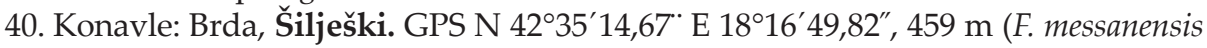
subsp. gracilis)

41. Konavle: Đurinići Donji. GPS N 42²8’03,53" E 18²7'04,98”, 230 m, 12. IV 2009. A unique specimen. (F. montana)

42. Konavle: Brda, Kuna Konavoska. GPS 42 ${ }^{\circ} 33^{\prime} 19,24^{\prime \prime}$ E 18²1'48,99”, 688 m, 23, 24. IV 2012, 8. IX 2013, 23. IV 2014, with Galanthus reginae olgae Orph. (F. messanensis subsp. gracilis)

43. Konavle: Brda, Velji do. GPS N 42³5’10,92” E 18¹5’31,31", 493 m, 24. IV 2012 (F. messanensis subsp. neglecta)

44. Konavle: Vitaljina. GPS N 42 $26^{\prime} 14,50^{\prime \prime}$ E $18^{\circ} 29^{\prime} 02,65^{\prime \prime}, 137$ m, 24. IV 2012 (F. messanensis subsp. gracilis)

45. Konavle: Njivice. GPS N 42 $33^{\prime} 54,57^{\prime \prime}$ E $18^{\circ} 20^{\prime} 57,02^{\prime \prime}, 748$ m, 9. IV 2002, 1. IV 2003, 4. IV 2003, 13. IV 2003, 23. IV 2012 (F. messanensis subsp. gracilis)

46. Pag island: Metajna. GPS N 44 $30^{\prime} 10,22^{\prime \prime}$ E $15^{\circ} 00^{\prime} 23,41^{\prime \prime}, 5-26 \mathrm{~m}, 13$. IV 2006, 26. III 2009, 17. IV 2009, 27. IV 2009, 13. IV 2012, 19. V 2012, 29. VII 2012, 12. IV 2013, 3. V 2013, 24. V 2013, 29. VI 2013, 21. IV 2014 (F. graeca subsp. thessala)

47. Lastovo island: Dubje. S N 42 $45^{\prime} 42,09^{\prime \prime}$ E $16^{\circ} 53^{\prime} 19,47^{\prime \prime}, 45 \mathrm{~m}$, 15. III 2008, a unique specimen (F. montana)

48. Lastovo island: Hom, GPS N 4245'04,28” E 1651'39,48”, 382 m, 21. III 2002, 15. IV 2003, 17. IV 2008 (F. montana)

49. Lastovo island: Struga. GPS N 42 $43^{\prime} 34,46^{\prime \prime}$ E 16 $53^{\prime} 3,15^{\prime \prime}, 29$ m, 31. III 2000, 20. III 2002. 10. IV 2013 (F. montana)

50. Lastovo island: Šupanj do, GPS N 4245’2,67" E 16051'6,06", 189 m, 10. IV 2013. A unique specimen (F. montana)

51. Dubrovnik suroundings, Gornji Brgat, GPS N 42³8'13,20" E 1809'02,99", 294 m, 23. IV 2012, 19. IX 2012, 7. IV 2013 (F. messanensis subsp. gracilis)

52. Southern Dalmatia: Osojnik, GPS N 42 42'03,17" E 18 $04^{\prime} 28,05^{\prime \prime}, 357$ m, 25. IV 2014 (F. messanensis subsp. neglecta)

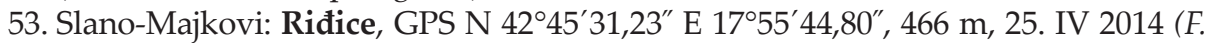
messanensis subsp. neglecta)

54. Mt. Kamešnica: Rože 1, GPS N 4339'26,48” E 1651'54,05”. 933 m, 23. IV 2014 (F. montana)

55. Mt. Kamešnica: Rože 2, GPS N 43³9'25,86" E 1652'37,75". 967 m, 23. IV 2014 (F. montana)

56. Mt. Kamešnica: Voštane-Blažević, GPS N 4337'55,36" E 1653'10,14", 847 m, 23. IV 2014 (F. montana)

57. Pelješac: Bila ploča, GPS N 4258'21,00" E 17¹6'19,03”, 426 m, 26. IV 2014, with Tulipa sylvestris L., Orchis pauciflora Tenore, Fraxinus ornus L. (F. messanensis subsp. neglecta)

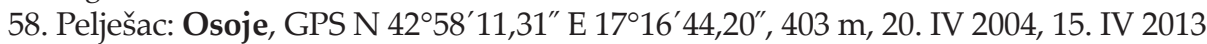
(F. messanensis subsp. neglecta)

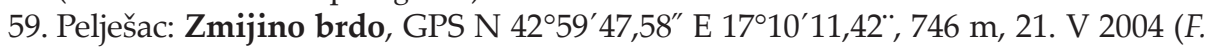
messanensis subsp. neglecta)

60. Hvar island: Sv. Nikola, GPS N 433' 68" E 16³6'10,14",1. V 2002, 15. IV 2005, 8. IV 2013, 24. IV 2014, 516 m (F. montana) 
61. Korčula island: Žrnovo, GPS N 4256'25,65" E 1706'54,32", 191 m, 20. IV 2006, 22. IV 2013 (F. messanensis subsp. neglecta)

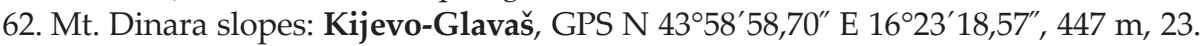
IV 2014 (F. montana)

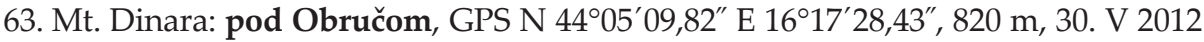
(F. montana)

64. Lika: Bunić, GPS N 44³9’54,87" E 15³6’30,34”, 792 m, 27. IV 2014. (F. montana)

65. Lika: Ljubovo, GPS N 4439'58,49" E 15³4’51,76", 966-990 m, 11. V 2011, 12. V 2011, 18. V 2012, 29. VII 2012, 30. III 2013, 24. IV 2013, 2. V 2013, 27. IV 2014, 21. V 2014, with Narcissus radiiflorus Salisb. (F. montana)

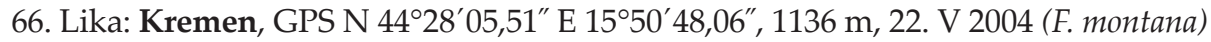

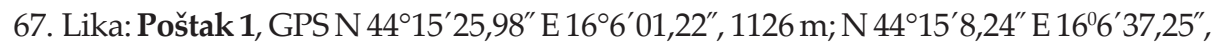
1318 m, 26. V 2012, 18. V 2013 (F. messanensis subsp. neglecta)

68. Lika: Poštak 2, GPS N 4415' 9,29”E 1606'38,43”, 1126 m, 22. V 2004, 28. V 2004, 10. V 2007, 18. V 2013, 20. V 2014 (F. montana)

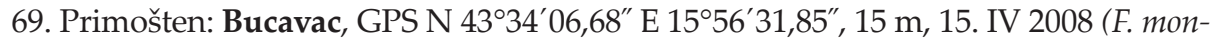
tana)

70. Podravina: Crni jarci, with Alnus glutinosa (L.) Gärtn. GPS N 46 $00^{\prime} 51,44^{\prime \prime}$ E $17^{\circ} 09^{\prime} 37,98^{\prime \prime}, 112 \mathrm{~m}, 21$. IV 2008. A unique specimen. (F. meleagris)

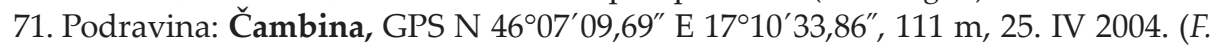
meleagris)

72. Podravina: Hlebine-Gabajeva Greda, GPS N 4608’03,01" E 1659'37,33", 120 m, 13. III 2014 (F. meleagris)

73. Podravina: Kutnjak, Josek, GPS N 46 ${ }^{\circ} 15^{\prime} 33,66^{\prime \prime}$ E $16^{\circ} 47^{\prime} 35,45^{\prime \prime}, 143$ m, 22. and 30. III 1995, 24. and 25. III 2012 (F. meleagris)

74. Mt. Velebit: Bunovac, GPS N 44²1'30,55" E 15³2'18,69”, 1204 m, 18. V 2013 (F. meleagris)

75. Mt. Velebit: Buljma, GPS N 4422'24,01" E 15²8’41,23", 1400 m, 16. VII 2013, 5. X 2013 (F. messanensis subsp. neglecta)

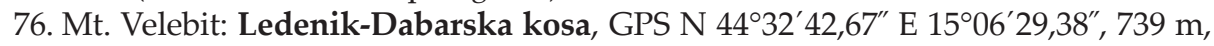
15. V 2004 (F. messanensis subsp. neglecta)

77. Mt. Velebit: Kukaline, GPS N 44³3'37,08" E 1506'10,61", 816 m (F. messanensis subsp. neglecta)

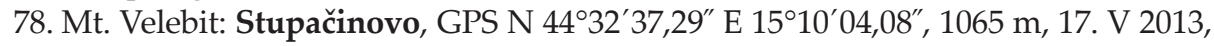
30. VI 2013 (F. messanensis subsp. neglecta)

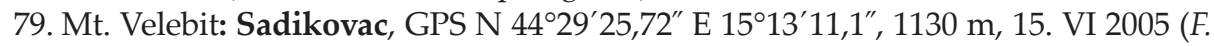
messanensis subsp. neglecta)

80. Mt. Velebit: Šušanj, GPS N 44³1'92,83" E 1507'09,26", 616 m, 27. IV 2014 (F. messanensis subsp. neglecta)

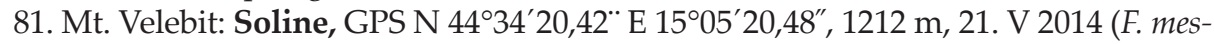
sanensis subsp. neglecta)

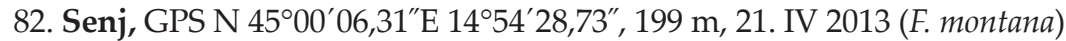

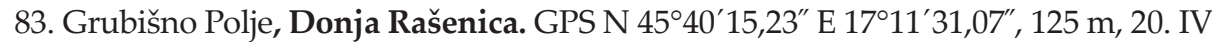
2009, 17. IV 2013, 20. III 2014 (F. meleagris)

84. Bjelovar: Kokinac, GPS N 4551'18,86" E 1654'18,65", 120 m, 19. IV 2005 (F. meleagris)

85. Varaždin: Zbelava, GPS N 46¹6'33,78” E 16²5'45,98", 159 m, 17. IV 2014 (F. meleagris) 
86. Mt. Papuk: Pliš, GPS N 45²2' 22,79" E 17³8'25,41", 527 m, 12. V 2012, 29. VII 2012, 1.V 2013, 12. IV 2014. (F. montana)

87. Mt. Biokovo: Veliki Troglav, GPS N 4320'21,20" E 1703’12,75", 1587 m, 19 V 2013 (F. messanensis subsp. neglecta)

88. Istria, Mt. Učka: Lanišće 1, GPS N 4508'13,13" E 14²11'37,84", 518 m, 13. IV 2014 (F. montana)

89. Istria, Mt. Učka: Lanišće 2, GPS N 4508’07,38” E 14¹1'48,80”, 483 m, 14. IV 2014 (F. messanensis subsp. neglecta)

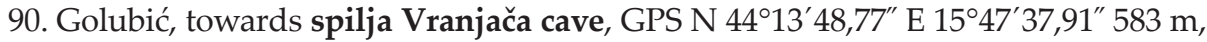
8. VI 2014 (F. messanensis subsp. neglecta)

\section{INTERPRETATION OF BIOMETRIC AND OTHER DATA}

Mutual comparison enabled us to determine how important and less important features can serve as criteria to distinguish each taxon clearly. A combination or a set of these features can also be considered important. Important features are those that in a certain combination are typical for a particular taxon and are at the same time essential for the differentiation of all relevant taxa in Croatia. Such important individual biometric properties are as follows: plant height; number, length, width and arrangement of leaves on the stem; number, length, shape and colour of flower; presence or absence of fascia on tepals, formation of tepal's apex, presence or absence of quadrant fields; length, width, shape, colour and edges of the nectarium. Of course, some ecological characteristics are also important, such as flowering time and altitude. All other features are less important. They can perhaps only help in closer analysis of intrapopulation and intraspecific variability or supplement a more detailed description of a taxon. Such properties, for example, are those relating to the fruit and seeds. An example of the population in Metajna on the island of Pag shows how the fruits in the same population can significantly differ in shape (Fig. 2).

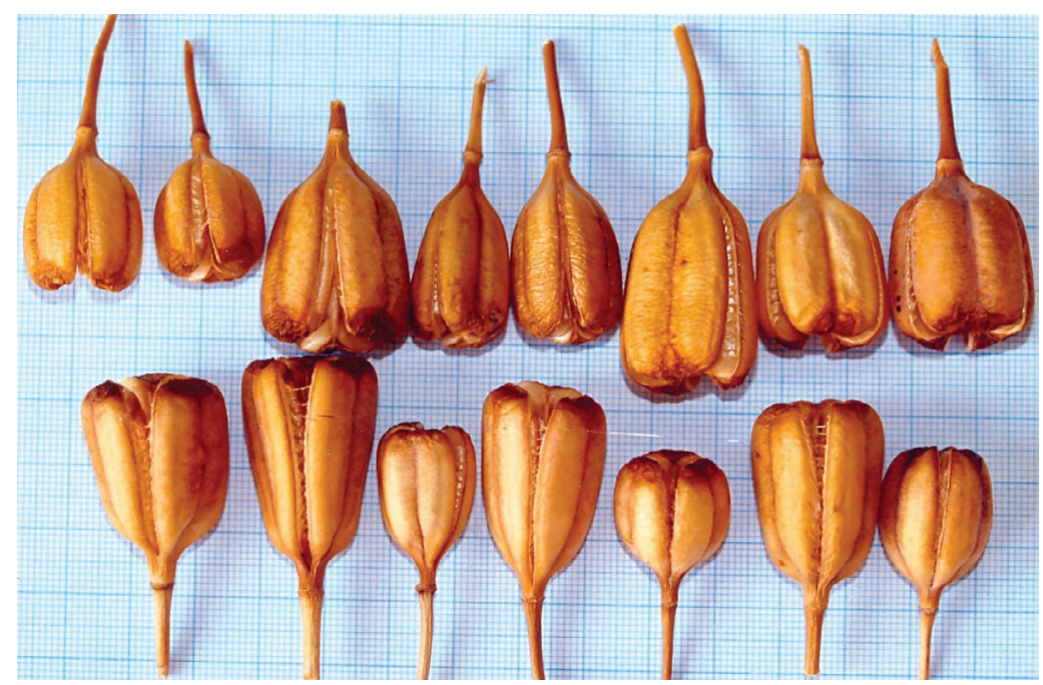

Fig. 2. Fruits of Fritillaria graeca Boiss. \& Spruner subsp. thessala (Boiss) Rix from the island of Pag. 


\section{SOME POPULATION FEATURES}

Because of our years of fieldwork and the discovery of many populations of taxa in the genus Fritillaria we were able to observe a number of biological phenomena that otherwise in a one-time reconnaissance and study of only one population or a small number of plants of the population can hardly be noticed.

The vegetation of an entire population may fail one or more years. That happened at several localities in 2012, 2013 and 2014. At the locality of Mt Poštak (Loc. Poštak 2) in these years, of thousands of specimens only a dozen or a few dozen flowered, and on the island of Hvar, Loc. 60 Sv. Nikola, in 2013 there was not a single specimen. The interesting fact of these phenomena, which may indicate the presence of two or more sympatric taxa, as is the case with populations at Blace (Loc. 4), can be expressed in such a manner that a specimen of one taxon can be completely absent in its vegetation one year, and a specimen of another sympatric taxon at the same time will grow in full vegetation. In the same habitat, therefore, two or more populations of different taxa can grow, but flower asynchronously, which is a good indicator for the distinction of species. The time difference as the cause of reproductive isolation can amount to 15-25 days.

In populations of taxa in the genus Fritillaria plant emergence, growth and flowering can take place very quickly and last for a short time.

In a large number of populations, flowers that have one or more holes on tepals formed by insect activity can be noticed. Among insects found on the genus Fritillaria, the lily beetle, Lilioceris lily (Scopoli, 1763), which feeds on plant components, is often present. Salticid spiders (Araneae: Salticidae) can inhabit dry fruits.

\section{TAXA OF THE GENUS FRITILLARIA IN CROATIA}

Based on detected populations and their specimens at 90 localities in Croatia and their mutual comparison and the determination of individual taxonomic status, the following taxa can be identified in Croatia:

\subsection{Fritillaria meleagris $\mathrm{L}$.}

Stem height (17-)20-30(-35) cm, naked or waxy. Leaves 4-6, alternate, linear, pointed tip and bent downwards, the longest $14-16 \mathrm{~cm}$ long, wide 5-8(-9) $\mathrm{mm}$. Flower one, very rarely two, (33-)42-43 mm long in the middle, (25-)28-32 mm wide, cylindrical and at the end of flowering slightly bell-like. Tepals purple brown to red brown and pink, with a clear pattern of squares, tip blunt or pointed, inner slightly longer and wider than the outside. Nectarium 9-10 mm away from the base perigonial leaf, linear, 9-11 mm long and 1-2 mm wide, clear edges, brown black, at the beginning of flowering brighter.

Notes: Heliophilous to semi-sciaphilous plant. It flowers from the end of March to mid May. We recorded it at nine localities. The taxon is known from about 120 localities (ILIJANić et al., 1998) and every year new ones are discovered. It mostly inhabits moist to swampy grasslands, meadows and pastures, and to a lesser extent deciduous forests and thickets of lowland areas of Croatia, and, rarely, mountains up to $1200 \mathrm{~m}$ in altitude. Populations may be small with a dozen or fewer specimens, as well as very large with thousands of specimens on areas up to $20 \mathrm{~km}^{2}$ and more. One of bigger populations is located near the village of Donja Rašenica (Loc. 83) on moist meadows and pastures. It is widespread all over Europe. The only proven large population in moist to swampy 
mountain meadows is the one from Bunovac valley on South Velebit mountain (possible danger of mines in this area!) where flowering lasts from the end of April to mid May. In this environmentally exceptional and isolated population we found a specimen that has opposite lower leaves; most of the plants have only 4 leaves, and one specimen has the upper leaves in whorls, which indicates a certain degree of diversity due to habitat specificity and isolation.

This species is protected by the Nature Protection Act of 1958 in the whole of Croatia and on the basis of the Nature Protection Act from 2013 (Official Gazzette, 2013a), it was also included in the Ordinance on Strictly Protected Species in Croatia (Official GazzetTe, 2013b).

Common names: prava kockavica, kockavica, košutica (Upper Podravina), obična kockavica, močvarni tulipan, kukovača, kapula (Schlosser-Vukot.).

Specimina visa: Croatia - Croatia in sylvis planinski ... Verbovec, Lovrečina et Dalmatia, 1875., Vukotinović, Ljudevit s.n. (ZA 6245); Ad Turan pone Karlovac, 17/4 1896., Rossi, Lj. s.n. (ZA 6254); u šumskom kraju „Paovo”, oko Soljana u Srijemu, gdje je zovu „pošulica”, Pokl. Marijan Lukačević, 17. IV 1907, Hirc s.n. (ZA 6249); Ad Orlovac pone Karlovac, 29/3 1908., Rossi, Lj. s.n. (var. albiflora) (ZA 6252); Novi Dvori, 23/III 1919., Gušić, B. s.n. (ZA 6251); Karlovac: livade kod Selca, mnogobrojna. 31/4 1922., Rossi, Lj. s.n. (ZA 6253); Karlovac, Orlovac, 13/4 1920., Rossi, Lj. s.n. (ZA 6244); Zaprešić, Novi Dvori, vlažna šuma, 15.III.1948., Ivo Horvat s.n. (ZAHO6580); Zaprešić, Novi Dvori, šuma hrasta i graba, 21.III.1948., Ivo Horvat s.n. (ZAHO6581, ZAHO41577 - 41584); Hrvatsko Zagorje, Pojatno ispod Vel. Vrha, 15.IV.1934. Ivo Horvat s.n. (ZAHO6582, ZAHO41585 - 41588); In sylvis ad Lovrečinam, St. Helenam, Jamnicam et alibi, s.d., Schlosser, K. s.n. (ZA 6259); In montibus circa Sign, s.d., Grubišić s.n. (ZA 6258); Vel. Gorica, Lekenik, Wormastiny, s.n. (ZA 6255); na vlažnih livadah u Posavini, s.d., Wormastiny, s.n. (ZA 6250); In... bei Kraljevec... Agram, April, s.d., Dr. Klinggräff s.n. (ZA 6248); Croat. et Slav., s.d., Schlosser, K. s.n. (ZA 6247); u nižjih šumah kod Lovrečine s.d., Schlosser, K. s.n. (ZA 6246); Hrvatska, s.d., Ivo Horvat s.n. (ZAHO41624 - 41679); Slovenia - Auf Sumpfwiesen bei Laibach, 28/4. 1883., Witting, E. s.n. (ZA 6261); Laibach, Litorale, s.d., Noé,? s.n. (ZA 6257); Carniolia, In pratis turfosis humidis agri Labacensis, 300 m.s.m., initio aprili, s.d., Paulin, A. s.n. (ZA 6260).

\subsection{Fritillaria messanensis Raf. subsp. gracilis (Ebel) Rix}

\section{Syn. Fritillaria gracilis (Ebel) Asch. \& Graebn., Lilium gracile Ebel}

Stem height (25-)35-50 cm, green. Leaves 6-10(-11), linear, the lowest linear lanceshaped, the largest up to $14 \mathrm{~cm}$ long, width up to $13 \mathrm{~mm}$, upper alternate, opposite or whorled, middle alternate or opposite, lower opposite to alternate. The leaves have a prominent central furrow, vertical or peak areas are slightly bent downwards. Lower leaves at almost half of the stem height, or low near the ground. Flower 1-2(-3), 28-40 mm long, wide in the middle (13-)23-27 mm, dark purple, cylindrical, without clearly visible quadratic fields. Tepals with rounded tip with a small nib, the widest in the upper part, without fascia, with poorly visible quadratic fields inside, or without them. Some flowers have tepals with tip bent outwards and leaves of the inner ring are partly yellow bordered on the outside. On some specimens a yellow green stripe that disappears towards the ends is observed. Nectarium $4-7 \mathrm{~mm}$ from the base of tepal, ovate to oblong, 6-8 $\mathrm{mm}$ long and $4 \mathrm{~mm}$ wide, greenish yellow with clear edges, the largest compared to all other taxa in Croatia. 


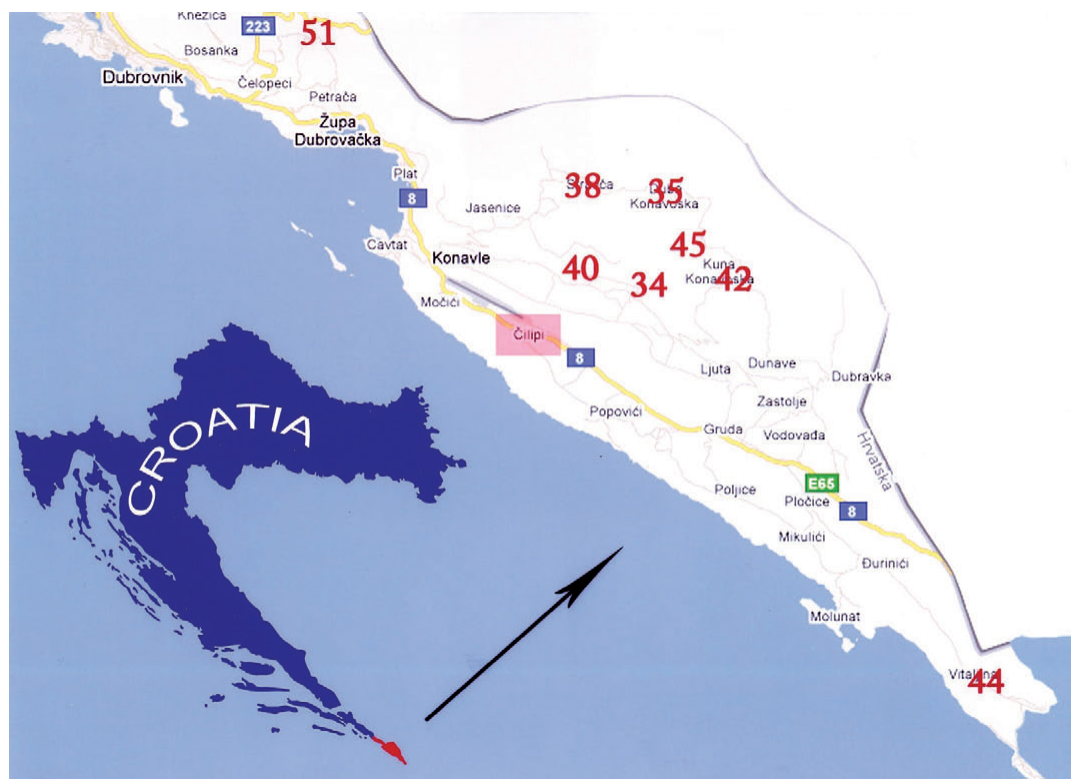

Fig. 3. Southern Croatia. Localities of Fritillaria messanensis Raf. subsp. gracilis (Ebel) Rix.

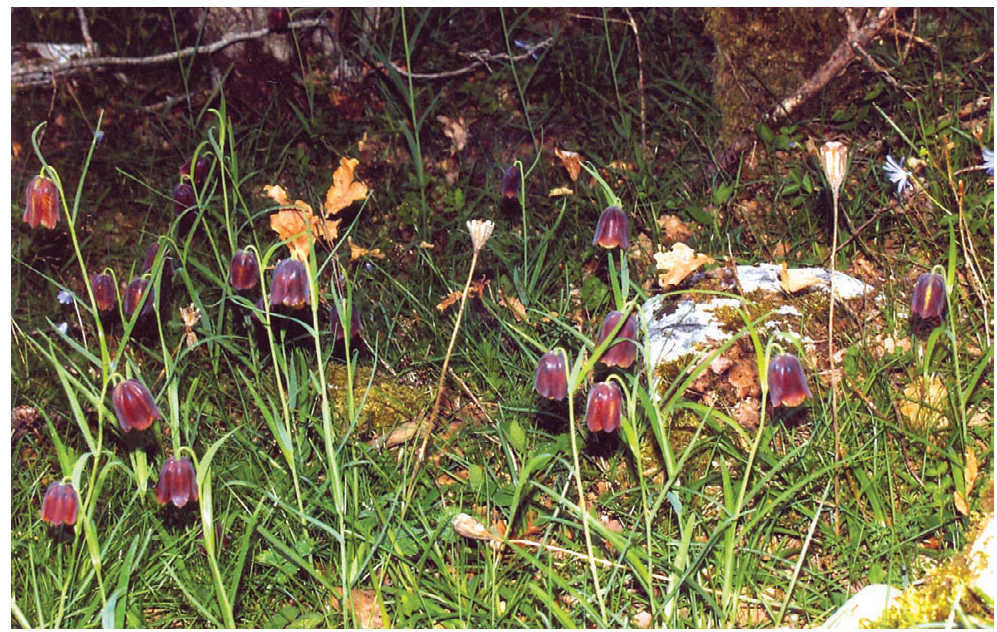

Fig. 4. Konavle, Kuna Konavoska. Flowering individuals of Fritillaria messanensis Raf. subsp. gracilis (Ebel) Rix.

Notes: Sciaphilous to semi sciaphilous, rarely heliophilous taxa, strong unpleasant odour during flowering. Discovered at eight localities in the southern part of Croatia with the western border at Gornji Brgat. Widespread in the southern part of the Balkan Peninsula and the former Yugoslavia. It flowers in southern Croatia during April just before the leafing of forest stands. Habitats are rare to dense deciduous forests with 


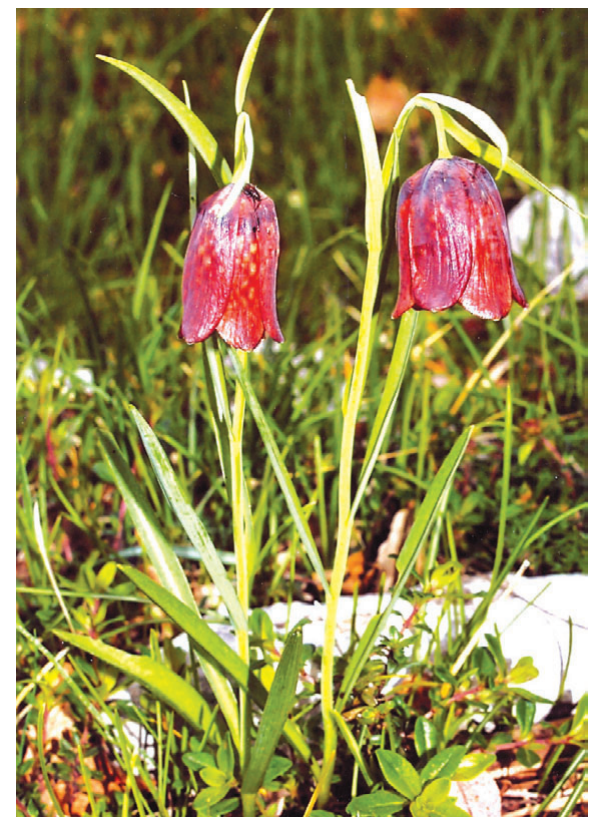

Fig. 5. Fritillaria messanensis Raf. subsp. gracilis (Ebel) Rix. Specimens from Njivice.

mixed stands and underbrush on calcareous soil, and rarely more or less covered and shaded terraces.

Common name: nježna kockavica, visibaba (Konavle: Kuna Konavoska).

(Exsiccate 3, no. 38601 (FCD), Figs. 3, 4, 5

Specimina visa: Croatia - Kod Voza na otoku Krku, 17/IV. 1881., brao A. Heimerl s.n. (ZA18453); In monte Brusnić ad Udbina, 14/7 1901., Rossi, 15.119 (ZA15661); Lit. croat: Ad portum Stinica loco dicto Plantaža, 19/4 1913., Rossi 24.318. (ZA 10156); Kuna Konavoska - Konavle, šuma hrasta te njezini rubovi, 688 mnv, 23. travanj 2012. Šešok, Damir s.n. (ZA 38601); Bosnia-Herzegovina - Obnv? Ovčarevo, 4. Mai 1885., leg. E. Brandis s.n. (ZA 10158); Prenj planina (Glogovo): In m. Obodić, ca 950 m, 22. IV. 1934., V. Loschingg s.n. (ZA 15662).

\subsection{Fritillaria messanensis subsp. neglecta (Parl.) Nyman}

Syn. Fritillaria neglecta Parl.

Stem height 37-45 cm tall, green. Leaves 7-10, green with a waxy coating and veins clearly visible from below, slightly spiral, the largest up to $14 \mathrm{~cm}$ long, width $14 \mathrm{~mm}$, the upper and middle alternate, more or less upright, lower leaves opposite to alternate and protruding almost horizontally. The leaves low on the stem, or absent in the lower third of the stem, all linear lance-shaped. Flower 1, rarely 2 or 3, 32-35 mm long, 23-29 mm wide, red brown, with yellow greenish fascia, barrel-shaped to slightly bell-shaped, no quadratic fields or they are barely visible. Tepals on top blunt, with a small nib, the widest in the upper third. Nectarium 5-7 mm from the base of tepal, oblong triangular to oblong oval, 4-6 mm long and 3-4 mm wide, down: clear brown edges, up: unclear edge and brighter. 
Note: This taxon has been recorded at 36 localities, from Istria, where it was described for the first time as endemic long ago within the Italian flora (PARLATORE, 1852), and again recently described in detail (Peruzzi et al., 2009) in the taxonomic status of a subspecies of Fritillaria messanensis s.l., from Istria to Konavle; it resides in the mountainous areas of the southern part of Croatia up to altitudes of approximately $1500 \mathrm{~m}$ (Mt Velebit, Mt Biokovo). According to chorological knowledge, this taxon has remained endemic to Croatia. It was unrecorded in recent literature concerning Croatian flora, except in RotTENSTEINER (2012), due to its usually being placed within F. messanensis subsp. gracilis, and in this respect it fully deserves its name. Habitats are mountain xerophylous grasslands on limestone with larger or smaller shares of bushes, but it is found also in the Adriatic, Mediterranean part of Croatia, as well as on the Pelješac peninsula (Loc. 57, 58) and the island of Korčula (Loc. 61) where it grows on scarce rocky xerophylous grasslands and rocky ground or within bush vegetation along the edges of forest stands (Loc. 59). Populations are small, up to 10 specimens, or medium in size with a few dozen specimens. It flowers during April. It is easily visible and recognizable with its well-known quadratic fields and distinctive fascia on the tepals. Lilioceris lily (Scopoli, 1763) is common on plants. Live jumping spiders Pellenes seriatus (Thorell, 1875) and Pellenes tripunctatus (Walckenaer, 1802) (Araneae, Salticidae) inhabited dry fruits in October 2013, Loc. 30.

Common name: zanemarena kockavica

(Exsiccate 4, No. 38602 (FCD), Figs. 6, 7, 8)

Specimina visa: Croatia - In monte Ljubičko brdo ad Oštaria, 11/7 1896., Rossi, 11.936. (ZA 10155); Velebit: In valle Šugarska Duliba, 24/7 1909., Rossi, 18.127. (ZA 10154); Lika, Lisac nad Glogovim kod Gračaca, 26.V.1924., Ivo Horvat s.n. (ZAHO41589 - 41598); Južni

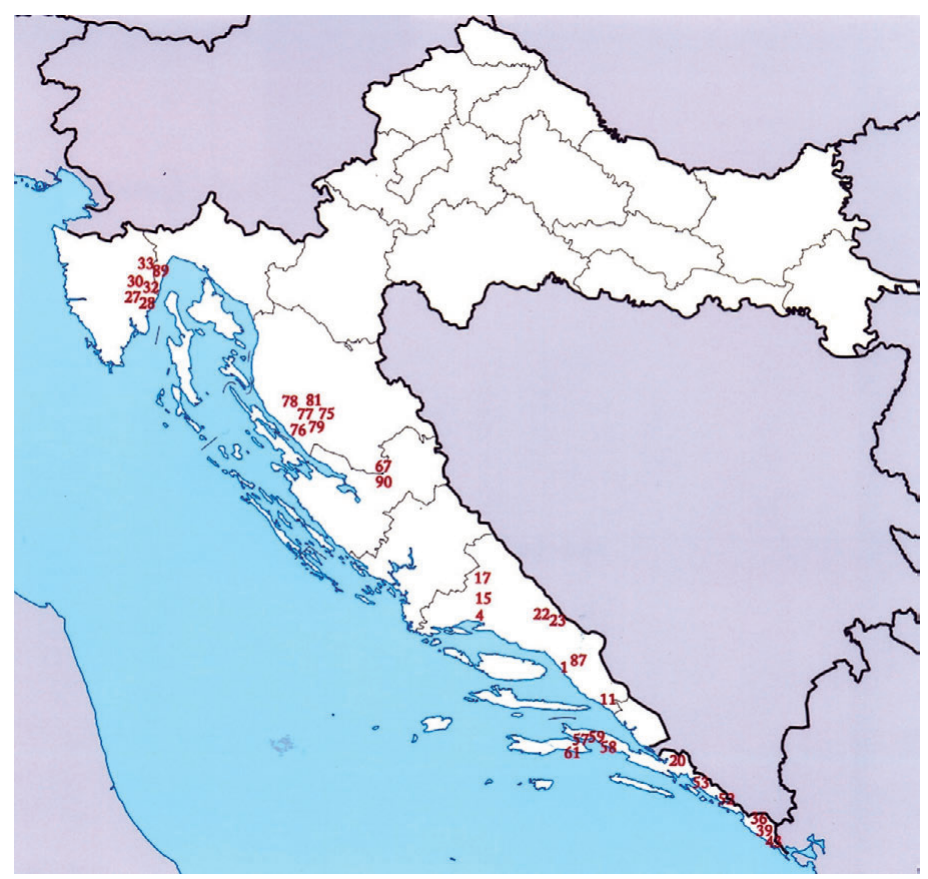

Fig. 6. Localities of Fritillaria messanensis subsp. neglecta (Parl.) Nyman in Croatia. 


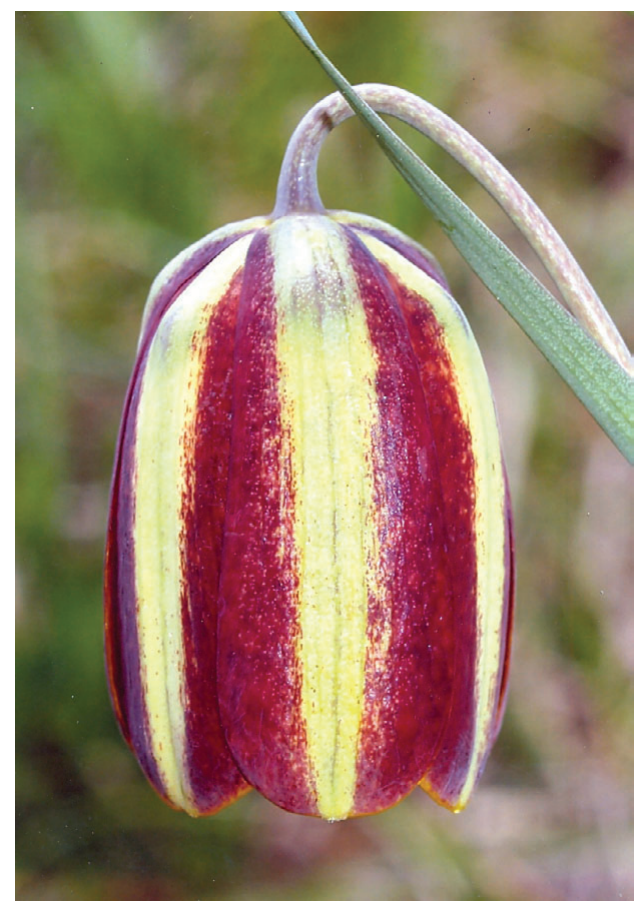

Fig. 7. Fritillaria messanensis subsp. neglecta (Parl.) Nyman. Flower.

Velebit, Badanj, 7.VI.1925., Ivo Horvat s.n. (ZAHO41599); Sjeverni Velebit, Šatorina, 14.VI.1934., Ivo Horvat s.n. (ZAHO41600); Južni Velebit, Badanj, pod stijenama na točilu u Festucetum pungentis as., 18.VI.1935., Ivo Horvat s.n. (ZAHO41601 - 41603); Južni Velebit, iznad Marasovca, 1670 m, obronak izložen SW, nagib 18-25으, Festuca pungentis as., 9.VI. 1938., Ivo Horvat s.n. (ZAHO41604 - 41610, ZAHO41612, ZAHO41613, ZAHO41615 - 41623); Poštak, travnati kamenjar, 1318 mnv, 18. svibanj 2013., Šešok, Damir s.n. (ZA 38602); Pod Prodolom - Učka, termofilni kamenjar po čistinama rijetke borove šume, 540 mnv, 12. travanj 2014., Šešok, Damir s.n. (ZA 38603); Dalmatia, s.d., Anonymus s.n. (ZA 18452); Dalmatinska Zagora, Vrgorac, Prapatnice, planina Matokit, iznad bazena, kamenjarski pašnjak, 17.04.2011., M. Vukojević s.n. (sub. F. orientalis Adams) (ZAGR 38837); Dalmacija, planina Kozjak, Malačka, vrh Orljak, kamenjarski travnjak, 10.04.2016., S. Bogdanović s.n. (ZAGR 41611); Jadranska magistrala, podno Velebita kod Jablanca, Balenska Draga, u šikari hrasta medunca, 10.04.2016., S. Bogdanović s.n. (ZAGR 41614); otok Korčula; Jelin rog, makija; 407 m n.v., izl. NW, 2002,Apr 03., E. Kletečki, s.n. (CNHM, 600:ZAG;7876:BOB); V. Paklenica, stjenovita livada, 1980:May, M. Balić s.n. (CNHM, 600:ZAG;3957:BOB); Hrvatska, Biokovo, Studenci, livada, 1500 m n.v., 2002:May03, E. Kletečki, s.n. (CNHM, 600:ZAG;4157:BOB)

\section{Variability:}

A plant with wide $(20 \mathrm{~mm})$ and shorter leaves, more or less upright and twisted and the lowest ones almost on the ground. Nectarium 4-5 mm from the base, oblong ovate, 5-6 mm long, 3-4 mm wide, dark brown to black, upwards brighter, clearer edges in the lower part, upwards unclear and irregular. 


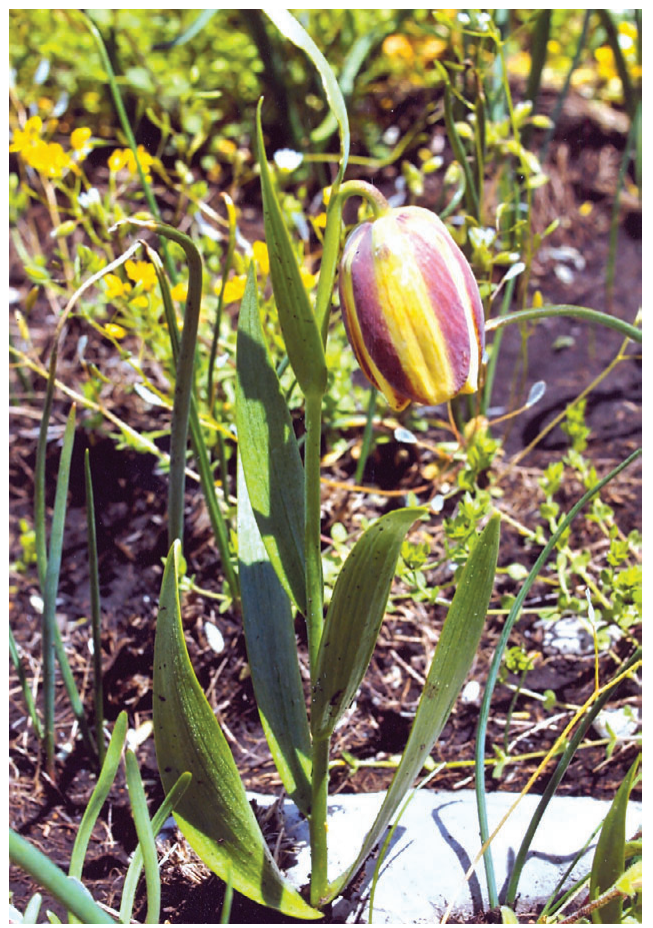

Fig. 8. Fritillaria messanensis subsp. neglecta (Parl.) Nyman. From Mt. Poštak with wide leaves.

A larger number of specimens of such features grow on Mt. Poštak (Loc. 67, Poštak 1) in a population whose number fluctuates from year to year. The variability of the taxon is very large in terms of distribution of leaves, plant size and characteristics of flowers, which creates greater possibilities for speciation and allocation of new subspecies or forms and requires further research. Loc. 67. Poštak 1; Loc. 78. Stupačinovo; Loc. 75 Buljma.

(Exsiccate 1, No. 38603 (FCD), Fig. 8)

\subsection{Fritillaria montana Hoppe ex W.D.J.Koch}

\section{Syn. Fritillaria degeniana J.Wagner, Fritillaria intermedia N.Terracc., Fritillaria liburnica Lengyel, Fritillaria orientalis auct., Fritillaria tenella auct., Fritillaria pollinensis N.Terracc.}

Stem height (17-)42-52(-60) cm, bluish to slightly waxy, stems and leaves are covered with dirty white lenticels. Leaves (5-)6-12, green, bluish, linear shaped, the longest up to $9 \mathrm{~cm}$ long, width $9 \mathrm{~mm}$, upper whorl-like or alternate or opposite, middle alternate, lower alternate, rarely whorl. Leaves spirally twisted and upright, between the middle and upper leaves a sizeable gap, grow also in the lower third of the stem. Flower 1, 2 frequently (about $20 \%$ of plants), rarely 4, (15-)22-30 mm long, (16-)18-24 mm wide, redbrown, barrel-shaped, rarely slightly bell-shaped, with poorly visible quadratic fields. Tepals on top blunt to pointed, greenish, reddish brown in the remaining part, without fascia but in its place more or less greenish stains, on the inside yellow green with dark spots, rarely tips bent slightly outward. Nectarium 4-5 mm from the base of tepal, honey- 
hole oblong, $15 \mathrm{~mm}$ long, 2-3 mm wide, clear edges to the unclear, dark brown, interior mostly greenish or black. From the honey-hole there is a yellowish greenish stripe about $2 \mathrm{~mm}$ wide, clear or less visible that extends all the way to near the top of the tepal.

Notes: This taxon has been recorded at 42 localities from Istria to Konavle, from continental parts of Croatia (Mt Papuk) to middle and south Adriatic islands (Hvar, Korčula). It usually inhabits mountainous bright xerophilic to mesophilic grasslands and rocky grounds with smaller or larger shares of shrubs, this species is rarely semi-sciaphilous within clearings of forest stands. There are populations of only a dozen specimens, but also those with a thousand or more. The largest populations known to us in Croatia are on the grasslands of Ljubova (Loc. 65) and Mt Poštak (Loc. 68, Poštak 2). Thus the recognized taxon is distinguished by the large variability in almost all physical characteristics. As with the previous one, more research within this taxon is needed in order to identify some possible subspecies or forms present in Croatia. In some localities the taxon is sympatric (Loc. 4, 23), growing together with populations of Fritillaria messanensis subsp. neglecta (Parl.) Nyman.

Flowers are visited by robber flies of the genus Laphria (Asilidae, Diptera). On a larger number of plants the beetle Lilioceris lily (Scopoli, 1763) has been observed. Many plants have holes in flowers or chewed leaves. A spider with cryptic coloration was also observed on one flower. Salticid spiders (Araneae, Salticidae): Pellenes seriatus (Thorell, 1875), P. tripunctatus (Walckenaer, 1802) and Phlegra sp. were discovered during October 2013 in dry fruits of taxa in the genus Fritillaria.

Common name: gorska kockavica

(Exsiccate 2, No. 38600 (FCD), Figs. 9, 10, 11)

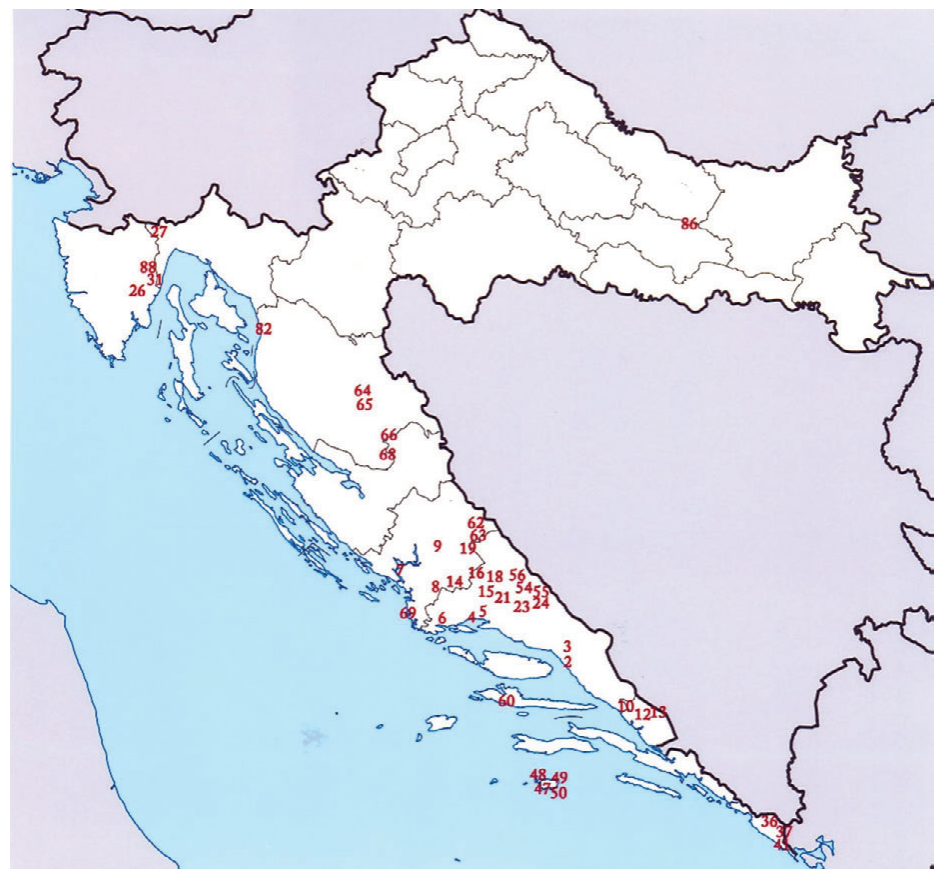

Fig. 9. Localities of Fritillaria montana in Croatia 


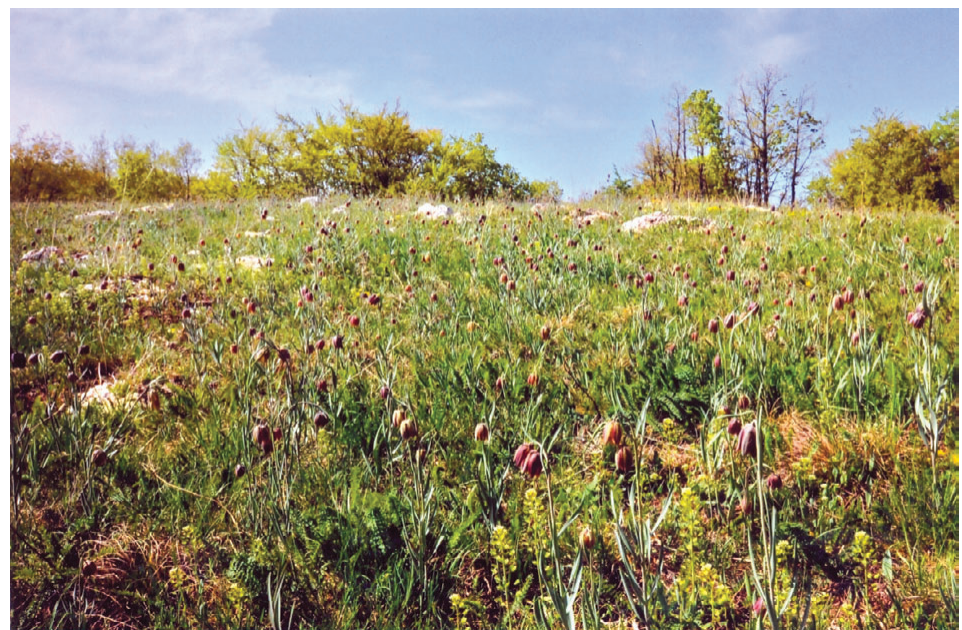

Fig. 10. Fritillaria montana, a part of the population at Ljubovo, Loc. 65.

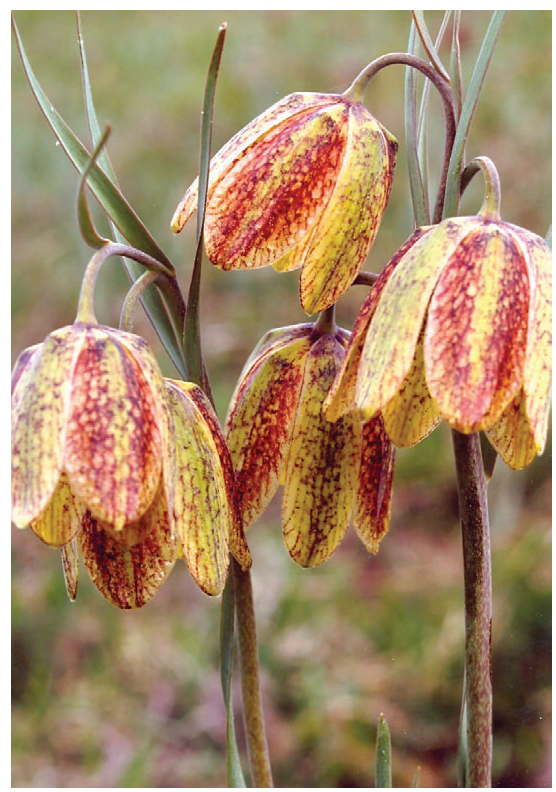

Fig. 11. Fritillaria montana, Ljubovo, flowers.

Specimina visa: Croatia - o. Lastovo; iznad Žegova, V. 1967., (ZA41571); Šibenik (Bilice-Vukovići), dračik, 23. 3. 1997., Milović s.n. (ZA 18451); Južni Papuk, Trinajstić s.n. (ZA41572); o. Lastovo: iznad Žegova, 2. IV. 1967., Trinajstić s.n. (ZA41571); Južni Papuk, greben Mališćak, istočna strana grebena, nadmorska visina od cca 400 pa i do $500 \mathrm{~m}$, zapadno od Velike oko 1,5-2 km, prorijedjena šuma hrasta medunca, dolomitna podloga, tlo obogaćeno humusom, dubine cca 5-15 cm. Sastojine su floristički bogate, ponegdje prevladava Bromus erectus Huds. subsp. fibrosus (Hack.) Stoj. et Stef., 
ekspozicija istočna, nagib i do 45\%. 27. travnja 1996, sakupljena biljka s cvijetom, 26. svibnja 1997 sakupljena biljka s plodom, Mirko Tomašević s.n. (ZA 18450); Ljubovo, gorska livada, 966 mnv, 04. svibanj 2013., Šešok, Damir s.n. (ZA38600); in pascuis montanis tractus Velebit, s.d., Dr. Jos. Calas. Schlosser s.n. (ZA 18460); otok Korčula; Jelin rog, makija; 407 m n.v., izl. NW, 2002, Apr03., E. Kletečki, s.n. (CNHM, 600:ZAG;4148:BOB) Italy - Prairies des montagnes calcaires „Carso" a la montagne Monte Spaccato et pres du village Kornjale aux environs de Trieste (Illyrie, Autriche), 2 mai 1858, M. deTommasini 24.316 (ZA41574); Prairies des montagnes calcaires „Carso“ a la montagne Monte Spaccato et pres du village Kornjale aux environs de Trieste (Illyrie, Autriche), 2 mai 1858, M. deTommasini (ZA41576); Littorale:...bei Trieste...Monte Spaccato...Padrich, 19. April 1857, Rudolf Mirich s.n. (ZA41573); In dictione Tergestina. In dumetosis montis Spaccato; solo calc. 350-400 m /locos classicus F. montanae Hoppe./, s.d., Marchesetti (ZA41575)

\subsection{Fritillaria graeca Boiss. \& Spruner subsp. thessala (Boiss.) Rix}

\section{Syn. Fritillaria thessalica Spruner, Fritillaria ionica Halácsy, Fritillaria thessala Boiss.}

Stem height (10-)21-25(-33) cm tall, waxy in the top part. Leaves 10-12, grow from ground level and relatively densely arranged, green, slightly covering the stem, the length of the largest is up to $10 \mathrm{~cm}$, width of the lower, linear lance-shaped is 8-14(-20) $\mathrm{mm}$, the middle and upper alternate, opposite or whorled, upright, the middle at an angle of $45^{\circ}$, the lower opposite, rarely alternate, almost horizontal. The lower pair of leaves grows at ground level and somewhat lower, mostly spiral or improperly crimped. Most of the leaves are in the lower half of the stem. Flower 1, rarely 2, 3(-4), length (12)26-27 mm, width up to $20 \mathrm{~mm}$, dark purple, sometimes greyish, barrel shape, near the end of flowering widely bell-like. Tepals with blunt rounded tip, or slightly pointed, with a clear yellow-green fascia, without or with poorly visible quadratic fields. Nectarium $7 \mathrm{~mm}$ from the base, roundish oblong, (3-)4-5 $\mathrm{mm}$ long and $3 \mathrm{~mm}$ wide, the edge towards the basis dark brown and clear and upwards vague, greenish grey colour and a bit darker than the fascia.

Note: This taxon was not previously reported for Croatian flora. It occurs only at Loc. 46, Metajna on the island of Pag, in a large population with a few demes and more than a thousand specimens, the majority of the inhabited area covers only a few meters to tens of meters from the sea level. Habitats are almost naked Mediterranean rocky grounds or rocky grounds with sparse xerophylous herbaceous vegetation or a few low shrubs. It is a heliophilous taxon that grows in habitats of various exposures.

The population covers the entire small peninsula south and southeast of the village of Metajna, but with individual specimens extends along the southern and northern slopes of the hill Panos (218 m). The total populated area is about 6-7 $\mathrm{km}^{2}$ (Map 4). It flowers from late March to late April. It inhabits habitats of predominantly southern and northern exposures and is well adapted to extreme temperatures and extreme soils in this part of the island of Pag. This is evidenced by the relatively large specimens in deeper ground that, on average, reach a height of $25(-33) \mathrm{cm}$, as well as those on almost bare limestone rocks, which are barely $10-15 \mathrm{~cm}$ high. Such plants are located within a radius of $5 \mathrm{~km}$ from the village Metajna.

Our plants fit well with the description of this taxon given in the Flora of Europe (RIX, 1980), which confirms the assumption about its occurrence in the former Yugoslavia 


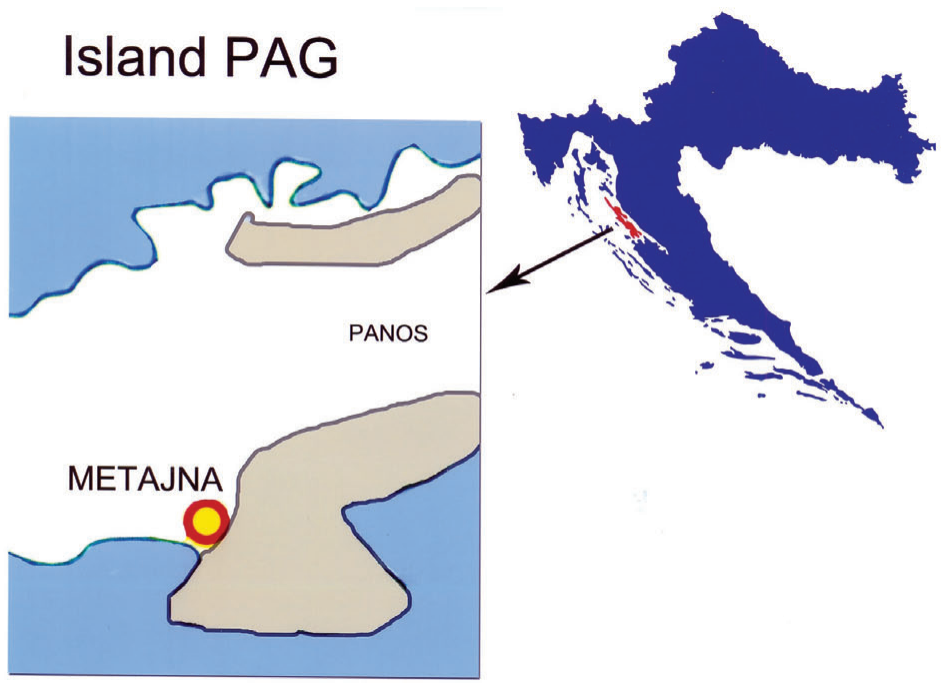

Fig. 12. Localities of Fritillaria graeca Boiss. \& Spruner subsp. thessala (Boiss.) Rix near the village Metajna on the island of Pag.

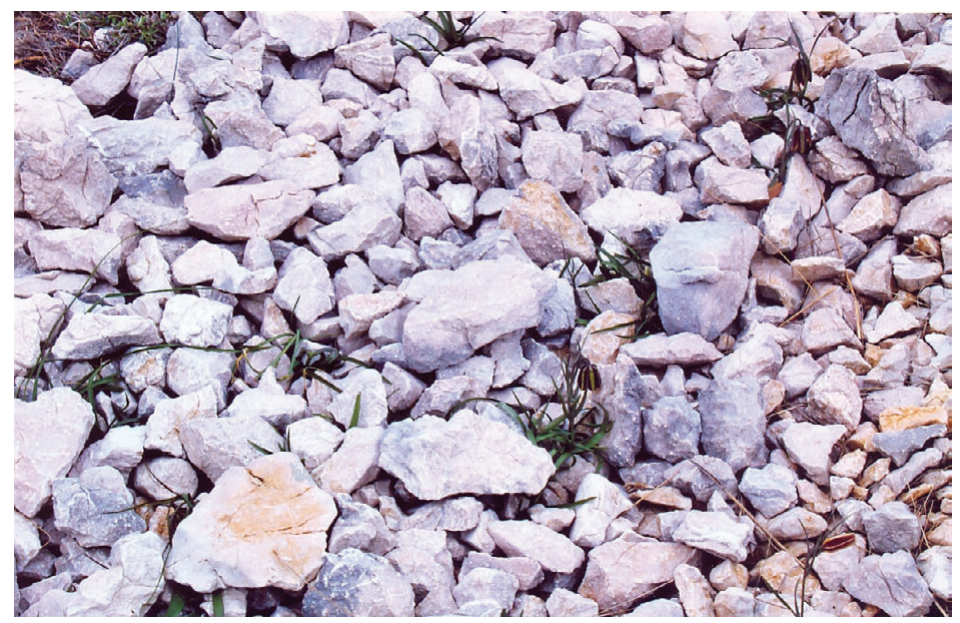

Fig. 13. Bare rocky ground as the habitat of Fritillaria graeca Boiss. \& Spruner subsp. thessala (Boiss.) Rix.

(BAzosu, 2011). Deviations are only in the distribution of leaves on the stem, predominantly in the lower part and curled lower pairs of opposite leaves and their position and growth at ground and even below ground level. In taxonomic terms, these differences are considered only as special forms of this taxon in habitats of the island of Pag, but this opens the possibility for further research into the taxonomic status of plants at this locality.

Common name: grčka kockavica, paška kockavica 


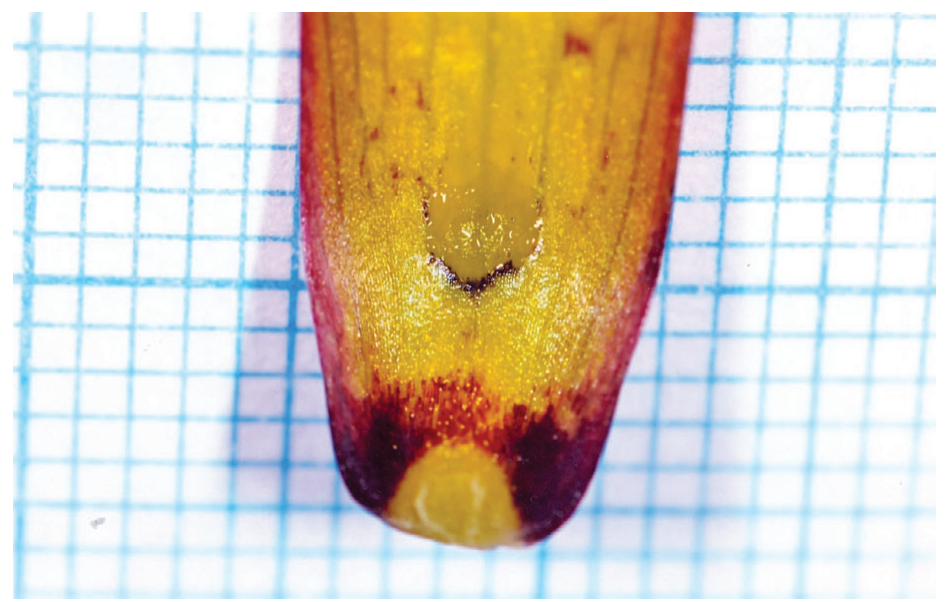

Fig. 14. Fritillaria graeca Boiss. \& Spruner subsp. thessala (Boiss.) Rix. Perigonial leaf from inside.

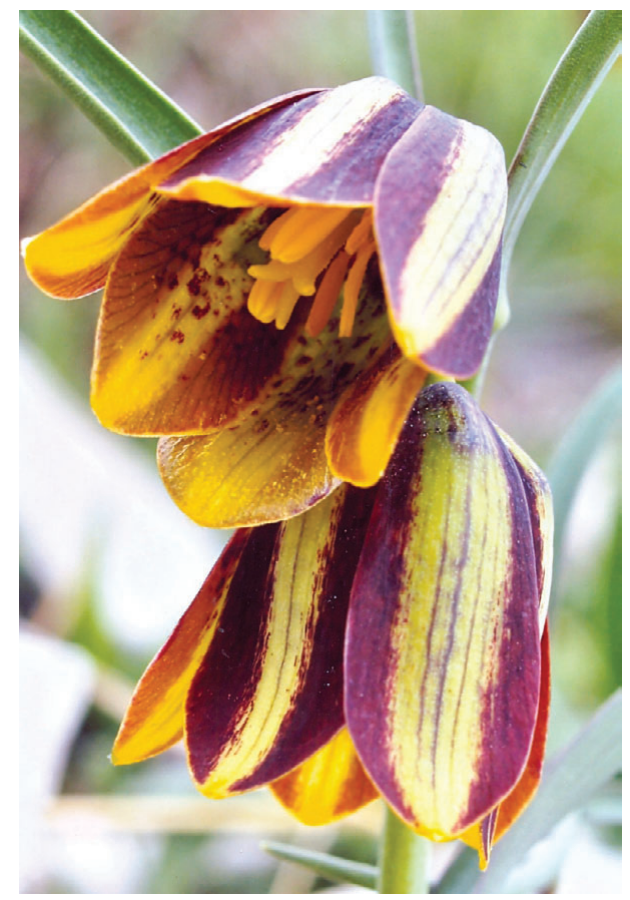

Fig. 15. Fritillaria graeca Boiss. \& Spruner subsp. thessala (Boiss.) Rix., flowers.

(Exsiccate 1 No. ZA40121 (FCD), Figs. 12, 13, 14, 15)

Specimina visa: Croatia - Otok Pag, Metajna, 5-26 m n. m., Croatia, 13.4.2006., Kranjčev, Radovan; Šešok, Damir s.n. (ZA 40121) 


\section{IDENTIFICATION Key for taxa in the genus Fritillaria in Croatia}

1 Perigonial leaves outside with clearly distinctive stripe (fascia) 2

1a Perigonial leaves outside without stripe or stripe unclear or partial 3

1

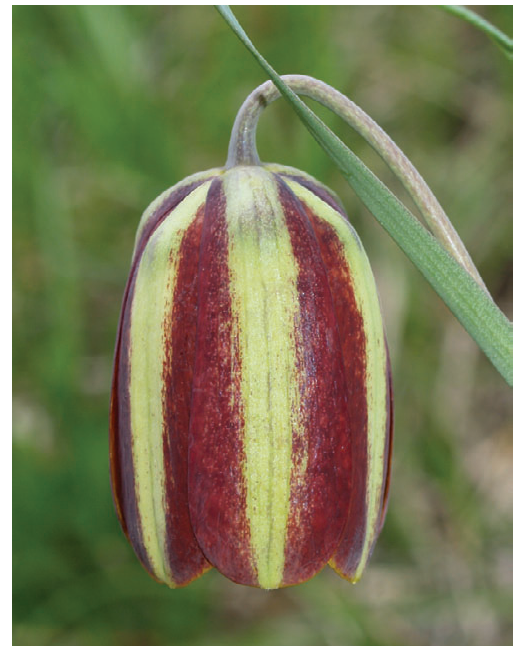

F. messanensis subsp. neglecta
$1 \mathrm{a}$

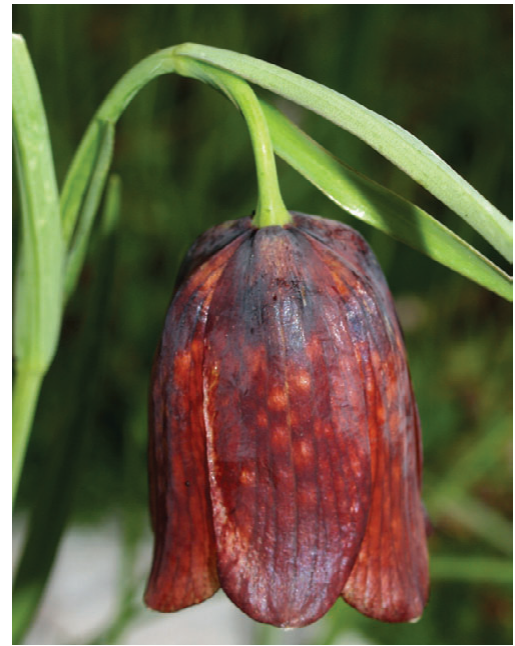

F. messanensis subsp. gracilis

2 The lowest leaves are wide and curved and prostrate to the ground level; low plant that grows in sub-Mediterranean and Mediterranean rocky ground near the sea (Metajna - island of Pag) ......... Fritillaria graeca Boiss. \& Spruner subsp. thessala (Boiss.) Rix

2

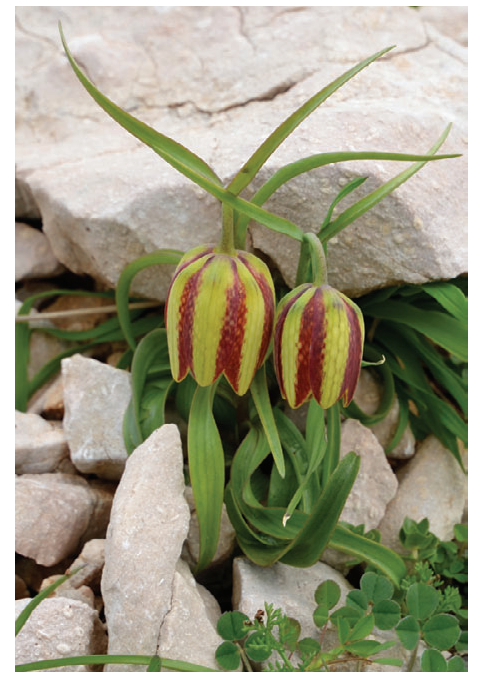

F. graeca subsp. thessala
$2 \mathrm{a}$

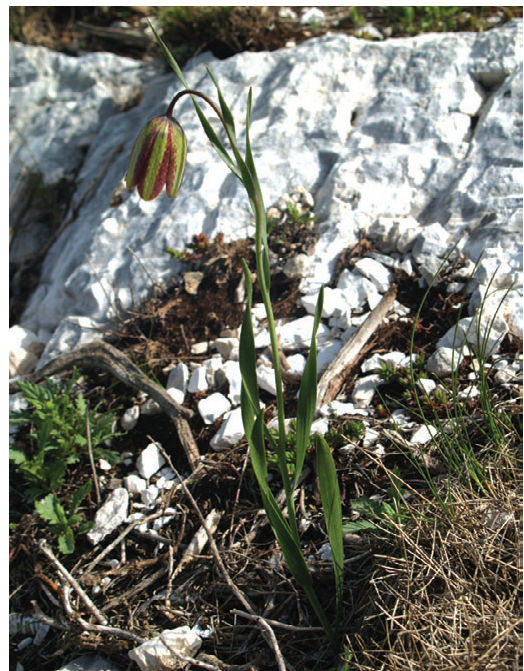

F. messanensis subsp. neglecta 
2a The lower leaves are erect or protruding, not prostrate on the ground; plant grows mostly on mountain grasslands and rocky continental, sub-Mediterranean and Mediterranean region Fritillaria messanensis subsp. neglecta (Parl.) Nyman

3 Nectarium oblong oval, 6-8 $\times 4 \mathrm{~mm}$; plant grows in forests and thickets in the south of Croatia (Dubrovnik area, Konavle)....Fritillaria messanensis Raf. subsp. gracilis (Ebel) Rix

3a Nectarium narrowly oblong or linear 4

3

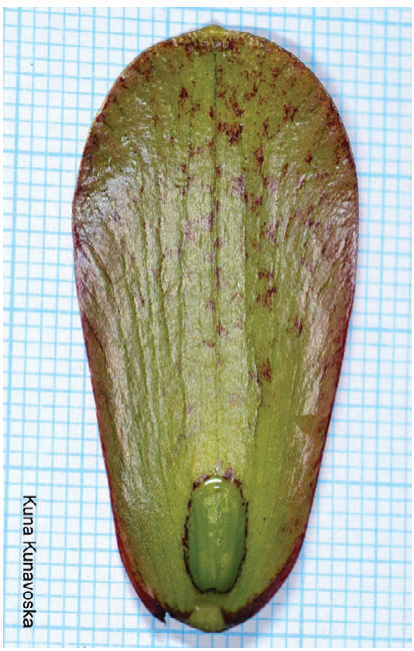

F. messanensis subsp. gracilis
$3 a$

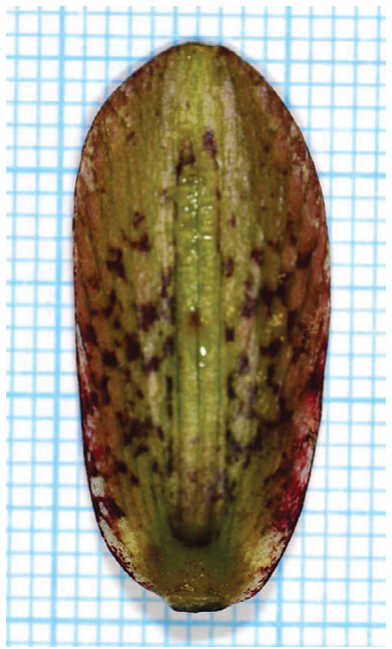

F. montana
$3 a$

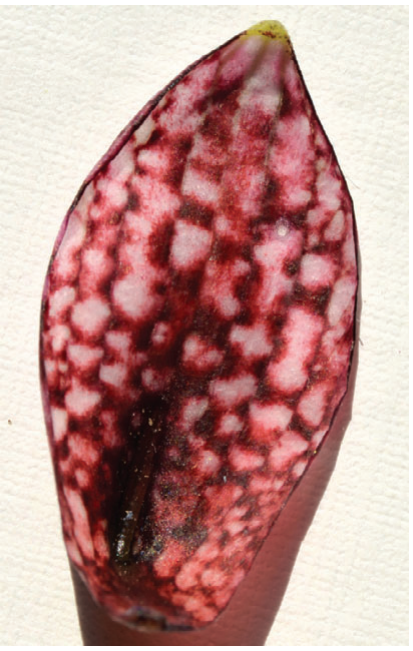

F. meleagris

4 The leaves always alternate, never opposite or in whorls of three; nectarium greenish yellow to black, narrowly linear and does not exceed half the length of the tepal; plant grows on wet meadows and forests mainly in the lowland part of northern Croatia Fritillaria meleagris L.

4a Leaves alternate, opposite or in whorls of three, bluish; nectarium linear to narrowly oblong, greenish yellow, reaching up to the tip of the tepal, sometimes difficult to notice; plant grows on grasslands, rocky grounds, thickets and sparse forests from the sea level to high mountain regions, never in moist soil

Fritillaria montana Hoppe ex W.D.J.Koch

\section{DISCUSSION}

When Fritillaria messanensis subsp. gracilis was mentioned in the Flora of Dalmatia (VISIANI, 1852) and in the Flora of Croatia (SCHLOSSER et al., 1869) and later, we believe that this was misapplied to the plants we know today under the name F. messanensis subsp. neglecta (Parl.) Nyman. The latter taxon is stated in the Flora of Italy (Parlatore, 1852) to be endemic to the area of Istria. Since then, two names have been applied to the same biological unit, and this was the first cause of confusion in relation to the recent Fritillaria messanensis subsp. neglecta (Parl.) Nyman (Peruzzi et al., 2009). This confusion continued with the unjustified introduction of the name F. involucrata All. (Schlosser et al., 1869) for the same floristic unit, which is somehow justifiable by the key that was 
used then, which mainly used some irrelevant morphological and anatomical features. Today we know that F. involucrata does not occur in Croatia, representing a species endemic to the Maritime Alps (Tutin et al., 1980).

Since F. messanensis subsp. neglecta (Parl.) Nyman was found at 36 localities, our opinion is that for now there are no legitimate reasons for undertaking protection measures, partly because a part of its population is already located in protected areas of nature in Croatia (Nature Park Učka, Nature Park Velebit, Nature Park Biokovo).

The description of this floristic unit (Nikolić, 2000; Nikolić et al., 2005; Alegro et al., 2010), as well as other data, referred to a misapplied name, i.e. F. messanensis Raf. subsp. gracilis (Ebel) Rix.

The problem is further complicated by the introduction of the names Fritillaria gracilis (Ebel) Asch. \& Graebn. and Lilium gracile Ebel, today understood as synonyms of Fritillaria messanensis Raf. subsp. gracilis (Ebel) Rix (HayeK, 1933; Degen, 1936, Kusan, 1969), which, for example, does not exist on Mt Biokovo. However, all these are actually misapplications for F. messanensis subsp. neglecta (Parl.) Nyman. The cause of this taxonomic confusion lies in the fact that within the polymorphic F. messanensis Raf., at first only three subspecies were recognized (KAMARI et al., 2006), and only later a fourth one (Peruzzi et al., 2009).

So, the question of whether researchers of Croatian flora knew about the existence of the authentic F. messanensis (Raf.) subsp. gracilis (Ebel) Rix in southern Croatia can reasonably be asked. Since systematic studies of Fritillaria are lacking, we are convinced that, to date, this subpecies had not been detected in Croatia. This is supported by the fact that nowhere so far in the area of Konavle, except for Mt Sniježnica referring to F. montana, has any locality been given or the name of any place or habitat in which it grows today.

After the field research conducted in southern Croatia, we determined the existence of the "true" F. messanensis Raf. subsp. gracilis (Ebel) Rix in the country, and presented a description, other information and a map of localities, which correspond to the information and description in contemporary literature. This subspecies is found only in southern Croatia, in Konavle and the Konavle hills in the far western localities in Gornji Brgat near Dubrovnik, i.e. on the Dubrovnik Riviera. Beside localities from the south of Croatia, in revised herbaria there are some specimens from localities that are situated outside this region. Today, two more taxa of Fritillaria inhabit this part of Croatia, partly sympatric with synchronous flowering. As sciaphilous and semi-sciaphilous plants they inhabit mostly forest habitats and Mediterranean macchia, which substantially differentiate them from F. messanensis subsp. neglecta (Parl.) Nyman. Populations in Croatia are a natural extension of the western part of its range in Montenegro, where it inhabits the mountains Rumija and Sutorman, its locus classicus. We found it at eight localities, from those very low, Loc. 44, Vitaljina at $130 \mathrm{~m}$ to about $750 \mathrm{~m}$ high in the hills of Konavle, Loc. 45, Njivice and documented it with photographs and exsiccates. With regard to the habitats and localities and the abundance of its populations, we believe that for now there is no real danger of the devastation and disappearance of this plant, and therefore, formal protection is not required. It should also be pointed out that F. messanensis Raf. subsp. messanensis (incl. F. sphaciotica Gand.) should be excluded from the Flora of Croatia (Nikоlić 2000), because according to the current knowledge, this subspecies does not exist in Croatia.

Fritillaria montana in regard to the taxonomic status represents a certain aggregate of morpho-anatomical characteristics (Bartolucci et al., 2009; Peruzzi \& Bartolucci, 2009). 
The biggest problem in identification is its relatively poorly visible linear nectarium, but if properly understood as a whole, and if studied on larger numbers of different populations, they can easily serve the purpose of reliable identification. A taxon with only one specimen plant was discovered at four localities (Loc. 47, 48 and 50 on Lastovo and Loc. 69 near Primošten). All specimens had a stem of about $60 \mathrm{~cm}$ tall, strong, with a lot of linear leaves and three flowers that were mostly smaller, down to half the usual size. Recently, a number of localities of F. montana (ToMAšEvić et al., 2012) were discovered on Mt Papuk and Mt Krndija, also confirmed here.

A lot of work was done in the research and description of F. liburnica B. Lengyel (Lengyel, 1931) in Istria. In the Flora of Europe (Tutin et al., 1980), F. montana Hoppe ex W. D. J. Koch and F. tenella M. Bieb. Have been united and together with F. liburnica B. Lengyel were treated as synonyms of F. orientalis Adams. This viewpoint is incorrect (Kamari, 1991).

Fritillaria graeca Boiss \& Spruner subsp. thessala (Boiss.) Rix which we detected in a large population only at one locality on the island of Pag (Loc. Metajna) and monitored through several years in its natural habitat in the vicinity of the sea, comparing it with other taxa of the genus Fritillaria in Europe (Tutin et al., 1980), represents a new taxon in the Flora of Croatia.

We believe that its habitats should be included into the list of habitats of the island of Pag (Mesić et al., 2009) and considered as exclusive habitats of this taxon and specially marked and excluded from any possible urban devastation or any other human activities, at least those parts of the habitat in the immediate area of the village Metajna.

In announcing the finding of the species Chouardia lakusicii (Silić) Speta (Hyacinthaceae) in the Dubrovnik area (Ruščić et al., 2012) and documenting its habitat with a description of the associated plant communities, F. messanensis Raf. subsp. gracilis (Ebel) Rix and F. graeca Boiss. \& Spruner are incidentally reported with no further information. Since the first taxon is cited outside the known distribution, it is our opinion this record is not reliable. The other taxon mentioned at this locality leaves doubt because it has not been properly documented.

Especially interesting are the relatively large populations of Fritillaria meleagris L. on the grasslands of Bunovac in southern Velebit where plants grow up to an elevation of $1200 \mathrm{~m}$ in a mountain climate and flower during the month of May. Because of these variations in the number and arrangement of leaves, we believe that it is not necessary to separate this population with regard to morphological features in comparison to many of its lowland populations in Croatia, but it certainly points to the need for its further protection within the Paklenica National Park.

From a chronological overview of botanical research in Croatia, it is evident that 12 taxonomically different taxa in the genus Fritillaria have been reported, which in itself speaks of the taxonomic confusion. However, today only four taxa are confirmed to occur, plus a fifth newly recorded: F. graeca Boiss. \& Spruner subsp. thessala (Boiss.) Rix.

The determination keys by which individual taxa have been differentiated (SCHLOSSER et al., 1869; Hayek, 1933; Pignatti, 1982; Domac, 1994) were often based on a series of irrelevant criteria such as those pertaining exclusively to the leaves, stem, seeds or parts of the pistil, and we believe that this was one of the reasons for the lack of successful differentiation of certain taxa. For a better understanding of taxonomic relationships and differentiation of certain taxa that occur in Croatia, we have tried to avoid these inadequacies by generating a key which, in our opinion, is based on several important features. 


\section{CONCLUSIONS}

We produced about 220 geo-coded localities of Fritillaria in Croatia, pertaining to five taxa. During the three-year period, and for some populations even much longer, we have discovered 90 populations. All taxa, with the exception of F. meleagris L., are supported with maps of localities. The populations are emphasized in their remarkable variability and distributed from lowland to highland and mountainous parts of Croatia, including some islands, from a few meters to over $1500 \mathrm{~m}$ above sea level. A part of the populations of different taxa can be sympatric, and in terms of flowering synchronous or asynchronous. Subject to certain environmental factors, the population dynamics, i.e. the number of specimens, from year to year, varies, and some populations may be completely absent for one or more years. Flowering lasts from mid-March to mid-May, depending on the altitude. Some populations of F. meleagris L. and F. montana are distinguished by their greater abundance of specimens and propagation on a large area, and they become dominant in certain plant communities during flowering time.

By establishing mutual taxonomic relationships based on the analysed populations and samples collected, we have identified the following species that should be entered in the List of the Flora of Croatia in the genus Fritillaria:

1. Fritillaria meleagris L.

2. Fritillaria messanensis subsp. neglecta (Parl.) Nyman

3. Fritillaria messanensis Raf. subsp. gracilis (Ebel) Rix

4. Fritillaria montana Hoppe ex W.D.J.Koch

5. Fritillaria graeca Boiss. \& Spruner subsp. thessala (Boiss.) Rix

\section{Acknowledgements}

We wish to express our gratitude for their enormous help in finding fritillary populations to: Marijan Radnić, Marko Randić, Krunoslav Arač, Ana Lemić, Vlado Prpić, Ante Delić and Roko Čičmir. We also express our deepest gratitude to our colleagues, herbarium curators who for this paper kindly made revisions of Fritillaria specimens from their hebaria: Vedran Šegota and Ivana Rešetnik, PhD (ZA and ZAHO, Faculty of Science, University of Zagreb), Sandro Bogdanović, PhD (ZAGR, Faculty of Agriculture, University of Zagreb) and Suzana Buzjak, PhD (CNHM, Croatian Natural History Museum, Zagreb).

Received January 15, 2015

\section{REFERENCES}

AdAmović, L., 1887: Građa za floru dubrovačku. I. Glas. hrv. naravosl. družtva 2, 161-167.

Adamović, L., 1911: Die Pflanzenwelt Dalmatiens, p. 1-137.

Alegro, A., Bogdanović, S., Brana, S., Jasprica, N., Katalinić, A., Kovačić, S., Nikolić, T., Milović, M., Pandža, M.,Posavec-Vukelić, V., Randić, M., Ruščić, M., Š́gota, V., ŠinceK, D., Topić, J., VrbeK, M. \& Vuкоvić, N., 2010: Botanički važna područja Hrvatske. p. 1-529. Školska knjiga, Zagreb.

Aquaro, G., Peruzzi, L. \& G. Cesca, 2007: Chromosome numbers of 20 flowering plants from ex-Yugoslav countries. Bocconea 21, 303-312.

Bartolucci, F., Caparelli, K. F. \& Peruzzi, L., 2009: A biometric study of Fritillaria montana Hoppe s.l. (Liliaceae) shows a single polymorphic species, with no infraspecific taxa. Plant Biosyst. 143(3), 516527.

BAzos, I., 2011: Fritillaria graeca. The IUCN Red List of Threatened Species. Version 2014.2. www.iucnredlist.org. Accessed on 21. 8. 2014. 
Degen, A, 1936-1938: Flora Velebitica. 1-4. Liliaceae: Fritillaria, p. 622-625. Budapest.

Domac, R., 1994: Flora Hrvatske. Priručnik za određivanje bilja. Školska knjiga. Pp. 1- 504.

HAyeK, A., 1933: Prodromus Florae peninsulae Balcanicae. 3. Band Monocotyledoneae. Liliaceae: Fritillaria, 3, 63-72.

IlijAnić, LJ., StANČić, Z., Topić, J. \& ŠEgulJA, N.,1998: Distribution and phytosociological relationships of snake's-head (Fritillaria meleagris L.) in Croatia. Acta Bot. Croat. 57, 65-88.

Kamari, G., 1991: The genus Fritillaria L. in Greece: taxonomy and caryology. Bot. Chron. 10, $253-270$.

Kamari, G. \& Phitos, D., 2006: Karyosistematic study of Fritillaria mesanensis s.1. (Liliaceae). Willdenowia 36, 217-233.

Kušan, F, 1969: Biljni pokrov Biokova. Jugoslav. Akad. Znan. 37, Acta Biol. 5, 179.

Lengyel, B, 1933-1934: Le Fritillarie del Monte Maggiore e la Fritillaria liburnica: nuova specie endemica. La rivista semestrale „Fiume” della Societa' di studi fiumani in Fiume, 11-12, 217- 257.

Mesić, Z., Peternel, H., Kušan, V., Križan, J., Antonić, O., Matočec, N., Pasarić, A., Hruševar, D., Grgurić, Z. \& BAjICA, M., 2009: Priručnik o kartama staništa Dalmacije. Prioritetna područja Pag i ostalo. Projekt COAST. Institut za primijenjenu ekologiju. 1-120. Zagreb.

Minailović, V., 1873: Flora senjske okolice. Školski program Gimnazije u Senju.

Nikolıć, T., 2000: Flora Croatica. Index Florae Croaticae. Pars 3. Natura Croatica 9, Suppl. 1, 1-324.

Nikolıć, T. \& Topıć, J., 2005: Crvena knjiga vaskularne flore Hrvatske. Ministarstvo kulture, Državni zavod za zaštitu prirode, Republika Hrvatska.1-693.

Official GazZetTe, 2013: Zakon o zaštiti prirode (Nature protection law), 80/2013.

Official Gazzette, 2013: Pravilnik o strogo zaštićenim vrstama (Ordinance on strictly protected species), $144 / 2013$.

Parlatore, F., 1852: Flora Italiana. Descrizione delle piante. Fritillaria. p. 408-416. Firenze.

Peruzzi, L. \& Bartolucci, F., 2009: Typification of the names within Fritillaria montana complex (Liliaceae) from central Mediterranean area. Candollea 64(1), 133-142.

Peruzzi, L., Caparelli, K., F. \& Bartolucci, F., 2009: Fritillaria messanensis subsp. neglecta (Parl.) Nyman, a fourth subspecies within Fritillaria messanensis Raf. (Liliaceae) from NW Balkans. Candollea. 64 (2), 237-244.

PignAtTi, S., 1982: Flora D’Italia. Vol. 3. Liliaceae: Fritillaria. 360-361. Edagricole.

Rottensteiner, W.K., 2012: Vorarbeiten zu einer „Flora von Istrien“. Teil XV. Carinthia 2, 601-662.

Rossi, LJ., 1930: Pregled flore Hrvatskog primorja. Prir. istr. JAZU. 17, 1-368.

Ruščić, M., Jasprica, N. \& Nikolić, T., 2012.: Chouardia lakusicii (Šilić) Speta (Hyacinthiaceae) in Croatian flora. Nat. Croat. 21(2), 373-380.

Schlosser, J. \& Vukotinović, LJ. F., 1869: Flora Croatica. Monocotyledoneae. Fritillaria. 1115- 1117. Zagreb. ŠILIĆ, Č., 1984: Endemične biljke. Sarajevo. p. 1- 227.

Tomašević, M. \& ZıмA, D., 2012: Nalazišta Fritillaria orientalis Adams (Liliaceae) na Papuku i Krndiji. Agronomski glasnik 5-6, 295-298.

Topić, J. \& J. Vukelić, 2009: Priručnik za određivanje kopnenih staništa u Hrvatskoj prema Direktivi o staništima EU. Državni zavod za zaštitu prirode. Zagreb. p. 1-376.

Tutin, T. G., Herwood, V. H., Burges, N.A., Moore, D.M., Valentine, D.H., Walters, S.M. \& Webb, D. A., 1980: Flora Europaea. Vol. 5. Rıx: Fritillaria, Liliaceae. Cambridge university press.

Visiani, R., 1842-1852: Flora Dalmatica. 1-3. Leipzig.

\title{
SAŽETAK
}

\section{Revizija roda Fritillaria (Liliaceae) u Hrvatskoj}

\author{
R. Kranjčev \& D. Šešok
}

U okviru svih temeljnih botaničkih istraživanja koja su provedena na prostoru današnje Republike Hrvatske (1852.-2012.), svojte u rodu Fritillaria su samo uzgred spomenute. Samo malobrojna botanička istraživanja provedena su u skorašnje vrijeme (TomAšEvıć \& ZıMA, 2012; Peruzzi \& Bartolucci, 2009; Peruzzi et al., 2009; Bartolucci et al., 2009; Ilijanić et al., 
1998), a odnosila su se isključivo na neke svojte u rodu Fritillaria, tako da se do danas u Hrvatskoj nisu u cijelosti poznavale sve svojte. Najčešće o njima nije postojala potrebna dokumentacija, bila su nedostatna terenska istraživanja i prepisivali su se stari, neprovjereni i netočni podaci, nisu obuhvaćena ostala relevantna staništa, a u literaturi je vladala zbrka oko njihovog taksonomskog statusa, sinonima, prostiranja i drugih značajki. Kroz cijelu kronologiju istraživanja, uključujući i sinonime, kao i nepostojeće svojte u Hrvatskoj, provlačila su se sve do danas imena 12 svojti u rodu Fritillaria u različitom taksononskom statusu. Od tih 12 , neprijeporne su ostale samo četiri, od kojih je jedna endemična (F. messanensis subsp. neglecta (Parl.) Nyman), a ostale tri su: F. meleagris L., F. messanensis Raf. subsp. gracilis (Ebel) Rix i F. montana Hoppe ex W.D.J.Koch.

S ciljem kompletnog utvrđivanja svojti u rodu Fritillaria na prostoru Republike Hrvatske, od 2012. do 2014., za neke svojte i od 2000., proveli smo terenska istraživanja njihovih populacija na 90 nalazišta u kontinentalnom i primorskom dijelu Hrvatske te na nekim otocima. Svojtu Fritillaria meleagris L. kao općepoznatu i najviše raširenu istražili smo u populacijama tek na 8 nalazišta u nizinskom dijelu Hrvatske i u planinskoj populaciji na Bunovcu u južnom Velebitu. Izvršena je i revizija herbarskog materijala u četiri herbarija (ZA i ZAHO, Prirodoslovno-matematički fakultet u Zagrebu; ZAGR, Agronomski fakultet u Zagrebu; CNHM, Hrvatski prirodoslovni muzej u Zagrebu).

Najviše nedoumica i prijepora izazivala je sve do danas Fritillaria messanensis Raf s.l. Premda je upravo iz Hrvatske (Istra, Učka) bila poznata već odavno (PARLATore, 1852), ali tek odnedavno u taksonomskom statusu podvrste (Peruzzi et al., 2009), endemična i realno postojeća svojta F. messanensis subsp. neglecta (Patl.) Nyman nije niti do danas ušla u popis hrvatske flore (Niкоцić, 2000). Došlo je do njezine zamjene s F. messanensis Raf. subsp. gracilis (Ebel) Rix., za koju smo utvrdili da se sve do danas nije niti poznavala u prirodi, na jugu Hrvatske, gdje smo otkrili njezine populacije (Konavle, Dubrovačko primorje). Osim nalazišta s juga Hrvatske u pregledanim herbarskim zbirkama postoje nalazi ove vrste s lokaliteta koji se nalaze izvan tog područja. Novu svojtu za hrvatsku floru otkrili smo u jednoj velikoj populaciji s nekoliko dijelova kod naselja Metajna na otoku Pagu, u sredozemnim kamenjarama svega nekoliko metara iznad razine mora. To je svojta F. graeca Boiss \& Spuner subsp. thessala (Boiss.) Rix. koja se u Hrvatskoj javlja s nekolicinom novih morfoloških obilježja. Prema tome, kao rezultat naših istraživanja danas u Hrvatskoj znamo za pet svojti kockavica: 1. F. meleagris L., 2. F. montana Hoppe ex W.D.J.Koch (Syn. F. degeniana J.Wagner, F. intermedia N.Terracc., F. liburnica Langyel,, F. tenella Auct., F. orientalis Auct. i F. pollinensis N.Terracc.), 3. F. messanensis subsp. neglecta (Parl.) Nyman (Syn. F. neglecta Parl.), 4. F. messanensis Raf. subsp. gracilis (Ebel) Rix (syn. F. neglecta Parl., F. gracilis (Ebel) Asch. \& Graebn, Lilium gracile Ebel), i 5. F. graeca Boiss. \& Spruner subsp. thessala (Boiss.) Rix (Syn. F. thessalica Spruner, F. ionica Halácsy, F. thessala Boiss.). 